Negotiating Self;

Domestic Architecture of the Shanghai Foreign Concession Districts

Kelly Woods Schantz

A Thesis submitted to the University of Virginia School of Architecture

In partial fulfillment of the requirements for the degree of Master of Architectural History

University of Virginia

May 2014

\title{
Committee Chair:
}

Professor Shiqiao Li

Committee Members:

Professor Richard Guy Wilson

Professor Sheila Crane 


\section{Table of Contents}

List of Illustrations

Introduction

Negotiating Identity, Class, and Culture

The Franklin Mansion

57 Columbia Road

The D.V. Woo House

Conclusion

Bibliography

Illustrations 


\section{List of Illustrations}

Fig. 1.1 Map of the Walled Chinese City of Shanghai, 1873.

From: Shanghai Gazetteer 上海县志 (1873).

Fig. 1.2 The Yangtze River, China

From: Eric Burger, The Yangtze River, 2013. From: Electric Treehouse

http://electrictreehouse.com/progress-and-the-yangtze-river/, (accessed April 20th, 2013).

Figure 1.3 Map Showing the American, British, French concessions and the walled Chinese City circa 1875. (Note: Oriented East to West)

From: Edward Denison and Guang Yu Ren. Building Shanghai: The Story of China's Gateway. Chichester, England; Hoboken, NJ: Wiley-Academy, 2006.

Fig. 1.4 Plan showing expansion of the Foreign Concessions in Shanghai.

From: Christian Henriot, Zu'an Zheng, Olivier Barge, and Sébastien Caquard, Atlas De Shanghai: Espaces Et Représentations De 1849 à Nos Jours. (Paris: CNRS Editions, 1999) 29.

Fig. 1.5 Shanghai's population distribution in 1929, per 500 people.

From: Christian Henriot, Zu'an Zheng, Olivier Barge, and Sébastien Caquard. Atlas De Shanghai : Espaces Et Représentations De 1849 à Nos Jours. (Paris: CNRS Editions, 1999) 99.

Fig. 1.6 Shanghai's population density per kilometer in 1929.

From: Christian Henriot, Zu'an Zheng, Olivier Barge, and Sébastien Caquard, Atlas De Shanghai: Espaces Et Représentations De 1849 à Nos Jours. (Paris: CNRS Editions, 1999) 98.

Fig. 1.7 Map showing location of case studies

Fig. 3.1 Estelle Oldham in Shanghai

From: Joseph Blotner, Faulkner: A Biography. New York: Random House, (1984).

Fig. 3.2 The Franklin House, exterior.

From: Tess Johnston and Dongqiang Erh, Frenchtown Shanghai: Western Architecture in Shanghai's Old French Concession. 1st ed. Hong Kong: Old China Hand Press, 2000.

Fig. 3.3 The Franklin House, exterior, archival photograph. 
From: Tess Johnston and Dongqiang Erh, Frenchtown Shanghai: Western Architecture in Shanghai's Old French Concession. 1st ed. Hong Kong: Old China Hand Press, 2000.

Fig. 3.4 Mount Vernon

From: Rob Shenk, Mount Vernon. Flickr, http://www.flickr.com/photos/rcsj/7428328252/sizes/l/ (accessed June 23, 2012).

Fig. 3.5 The Franklin House, interior.

From: Tess Johnston and Dongqiang Erh, Frenchtown Shanghai: Western Architecture in Shanghai's Old French Concession. 1st ed. Hong Kong: Old China Hand Press, 2000.

Fig. 4.1 The Ideal Home, Cover.

From:The Ideal Home, Volume 1 No. 1, October to December, 1919.

Fig. 4.257 Columbia Road, exterior and garden

From: Lenore Hietkamp, "Understanding Laszlo Hudec, Shanghai Architect."

Diamond River Books, accessed 02/01, 2014, http://www.heatherfieldediting.com/Hudec/index.html.

Fig 4.3 57 Columbia Circle, plan

Xiahong, Hua and Michelle Qiao. Shanghai Hudec Architecture. Shanghai: Tongji University Press, 2012.

Fig. 4.4 57 Columbia Road, plan showing landscaping

From: Lenore Hietkamp, "Understanding Laszlo Hudec, Shanghai Architect." Diamond River Books, accessed 02/01, 2014, http://www.heatherfieldediting.com/Hudec/index.html.

Fig. 4.5 Student in woodcarving workshop in Jesuit orphanage

Lenore Hietkamp, "Understanding Laszlo Hudec, Shanghai Architect." Diamond River Books, accessed 02/01, 2014, http://www.heatherfieldediting.com/Hudec/index.html.

Fig. 4.6 57 Columbia Road, foyer

From: Lenore Hietkamp, "Understanding Laszlo Hudec, Shanghai Architect." Diamond River Books, accessed 02/01, 2014, http://www.heatherfieldediting.com/Hudec/index.html. 
Fig. 4.7 57 Columbia Road, dining room

From: Lenore Hietkamp, "Understanding Laszlo Hudec, Shanghai Architect." Diamond River Books, accessed 02/01, 2014, http://www.heatherfieldediting.com/Hudec/index.html.

Fig. 4.7 57 Columbia Road, dining room

From: Lenore Hietkamp, "Understanding Laszlo Hudec, Shanghai Architect." Diamond River Books, accessed 02/01, 2014, http://www.heatherfieldediting.com/Hudec/index.html.

Fig 5.1 D.V. Woo House, view from the garden

From: "Fragments of Shanghai; Old Shanghai Architecture." The Flying Room, accessed 11/2, 2013, http://www.theflyingroom.com/blogs/news/7515666-fragments-of-shanghai-old-shan ghai-architecture.

Fig 5.2 D.V. Woo House, interior stairwell featuring metal details

Tess Johnston and Deke Erh. Art Deco Shanghai. Hong Kong: Old China Hand Press, 2006.

Fig 5.3 D.V. Woo House, interior stairwell featuring metal details

Tess Johnston and Deke Erh. Art Deco Shanghai. Hong Kong: Old China Hand Press, 2006.

Fig 5.4 D.V. Woo House, interior stairwell

From: "Fragments of Shanghai; Old Shanghai Architecture." The Flying Room, accessed 11/2, 2013, http://www.theflyingroom.com/blogs/news/7515666-fragments-of-shanghai-old-shan ghai-architecture.

Fig 5.5 D.V. Woo House, ground floor plan

From: Xiahong, Hua and Michelle Qiao. Shanghai Hudec Architecture. Shanghai: Tongji University Press, 2012.

Fig 5.6 D.V. Woo House, first floor plan

From: Xiahong, Hua and Michelle Qiao. Shanghai Hudec Architecture. Shanghai:

Tongji University Press, 2012.

Fig 5.7 D.V. Woo House, second floor plan

From: Xiahong, Hua and Michelle Qiao. Shanghai Hudec Architecture. Shanghai:

Tongji University Press, 2012. 
Fig 5.8 D.V. Woo House, third floor plan

From: Xiahong, Hua and Michelle Qiao. Shanghai Hudec Architecture. Shanghai:

Tongji University Press, 2012.

Fig 5.9 D.V. Woo House, dining room

From:吴同文住宅, 上海市杨浦区图书馆, accessed 2/12, 2014.

http://www.yplib.org.cn/upload/htmleditor/image/090330100544.jpg 


\section{Acknowledgements}

I would like to thank my thesis committee members, Professor Shiqiao Li, Professor Richard Guy Wilson, and Professor Sheila Crane. Your support, patience, criticism, and insight have pushed me to newer and better iterations of my original research goal. I look forward to working with all of you more over the next four years.

My research in Shanghai would not have been possible without the generous support of the Dean's Research Fund, and the Lambert Woods Scholarship. I am very grateful for this support. I am also indebted to my local guides and hosts. Tess Johnston, another UVA graduate whose work towards the documentation and preservation of Shanghai's architectural heritage is nothing short of love. To Jessica Gleeson and Nick Brown: your incredible generosity, friendship, and thoughtfulness were unexpected and moving, and vividly colored my time in Shanghai.

I would also like to thank my wonderful parents, Shannon Louise Woods and Gordon John Schantz, whose support, patience, and clarity of mind translated into my sanity during the writing process. 


\section{Introduction}

"Architecture inevitably reflects the deeper beliefs of an age, it bears witness to current feeling about nature, about society, and about the very possibility of human improvement. . . architecture is like the human personality. It consists of body and spirit." Lewis Mumford, The South in Architecture (1941)

Shanghai's sudden rise on the international stage in the mid-19th century and into the 20th provided a terrain uniquely responsive to transnational negotiations. In this thesis I argue that the employment of specific forms of Western architectural language in the domestic sphere was a manifestation of these negotiations, and provides a fruitful lens for revealing Shanghai's diverse history. Using the work of theorists who discuss domestic spaces, this research approaches the city as a text and cultural monument, and will discuss

Shanghai's symbolic representation in terms of negotiations of identity, culture, and class. After discussing the theoretical voices involved, several case studies from the Shanghai domestic sphere will provide evidence supporting these theories.

Shanghai of the late 19th and early 20th century was a treaty port under the control of foreigners and, due to the fluid nature of international trade, the population was often in flux. Compared to other Chinese cities, the fluidity of Shanghai's multinational community provided residents more opportunity for flexibility and mobility. Whether Chinese or Western, when newcomers arrived in Shanghai they had the opportunity to (re)invent themselves. Yet, in many ways the city was neither immune to the influences and forces of Chinese and Western capitals, nor to the internal structures of power. Rather, these forces were recognized as such and often co-opted by stakeholders and used to their benefit. As a new and rapidly growing city, Shanghai of the late 19th and early 20th century was a 
shifting terrain of culture and memory; people had the opportunity to negotiate their own society and even history unencumbered by the past, memory, or tradition. In this case, the term negotiation describes the purposeful exchanges between Shanghai residents, intended to achieve shared understanding, or mutually-understood expression of self. Identifying clear means of expression that advanced the agenda or standing of the individual was the method of negotiation. These exchanges were carried out on many different stages, including domestic architecture. Strategies of negotiation in architecture include the use of familiar markers of power, solidity, strength, and beauty in order to achieve shared understanding.

For example, one goal of negotiation for Shanghai architect, Laszlo Hudec, was to emphasize his wife's family ties to England by building a large home in the British Tudoresque style. As a Hungarian after WWI, he was seen not only as an enemy of British, American and French residents but also was not afforded legal protection under any of the extraterritoriality treaties. A British home may have allowed him to more easily maneuver within Shanghai society and business realms. Negotiations were thus specific to each architectural commission, and constructed by both the architect and the client.

\section{Historical Background}

Over the past two centuries Shanghai has been the territorial object of desire for many nations. When Daoguang Emperor, the eighth emperor of the Manchu Qing Dynasty, signed the Treaty of Nanking in 1842 he opened up China's ports to trade with foreign countries. Under the terms of the treaty China made significant economic and political concessions to Britain. Other Western countries, including France, claimed similar 
privileges in China and were awarded similar rights. Today, there are echoes of mid-19th century Western claims to territory in Shanghai, as scholars debate the origins of the modern city attempting to discern the roots of modernity and the factors which lead to its success on the international stage.

Shanghai, a bustling commercial city surrounded by high walls at the mouth of the Yangtze River already essential to trade on the national level, became an important international port during the later half of the 19th century. [Fig. 1.1] The foreign concessions' location on the banks of the Huangpu River facilitated trade with the Chinese merchant guilds who controlled trade in the interior of China up the Yangtze. ${ }^{1}$ The Huangpu is the key to Shanghai's strategic economic importance as a gateway into greater China, as it is the last major tributary of the Yangtze River before it meets the ocean. [Fig. 1.2] A period of enormous growth followed the opening of the port of Shanghai, marked by rapid building and modernization. This growth lasted until the mid twentieth century when the transition to Communist power led to an economic downturn in Shanghai, and the exodus of all foreigners as China closed its borders.

The Treaty of Nanking set the stage for Shanghai's modern urban development. Select Chinese sea ports were open to trade with the West for the first time in centuries. ${ }^{2}$ By awarding autonomous, self-ruling districts in treaty ports, including Shanghai, to foreign countries the treaty created foreign districts that would expand again and again in the century to come following natural and artificial boundaries. For the city of Shanghai, this marked the beginning of an influx of foreigners bent on making their fortunes in China while

\footnotetext{
1 John King Fairbank, The Cambridge History of China; Republican China, 1912-1949, Part 1. (Cambridge: Cambridge University Press, 1993) 128-132.

2 Ibid., 131.
} 
living in the foreign concession districts established by the treaty. The settlements were initially under British and French control. [Fig 1.3] The British area, called the British Settlement, was later joined by America to become the International Settlement, and run by the powerful multinational Shanghai Municipal Council. It was located north of the French settlement. The French settlement was called the French Concession, and while initially part of the Shanghai Municipal Council, eventually split to form a separate governing body called the Municipal Administrative Council. These two foreign-run settlements are also called the Foreign Concession Districts. They worked closely together, and their borders were fluid; men often worked in the International Settlement but lived in the tree-lined French Concession. The settlements were powerful, autonomous states within China, the governing bodies not only levied their own taxes, but also boasted powerful armed forces at their fingertips. ${ }^{3}$

Throughout the decades following the treaty, Shanghai attracted merchants, tradespeople, and sojourners from both China and the West. Located adjacent to one another, each concession district frequently expanded westward, absorbing more land as the population of Shanghai grew. While at first foreigners attempted to live segregated lives within Concession Districts, this would eventually change. Outside the concessions, the old Chinese walled city also grew and prospered, as Western merchants were obligated to work with the dense and powerful network of Chinese merchants in order to sell their goods beyond Shanghai. ${ }^{4}$ These two communities were dependent upon one

\footnotetext{
${ }^{3}$ Edward Denison and Guang Yu Ren. Building Shanghai : The Story of China's Gateway. (Chichester, England; Hoboken, NJ: Wiley-Academy, 2006) 80-81.

${ }^{4}$ Marie-Claire Bergère, Shanghai; China's Gateway to Modernity. (Stanford: Stanford University Press, 2009) 50 .
} 
another. Economic success for each group hinged upon their ability to cooperate with the other. These groups also lived side by side in densely mixed neighborhoods.

By the 1930's Shanghai was the center of a cosmopolitan cultural space that linked China to major cities around the globe. The 5th largest city in the world, Shanghai was connected to other cities by a network of sea routes that linked many international ports, and supported marketing, transportation, and tourism. ${ }^{5}$

\section{Westerners in Shanghai}

Westerners in Shanghai were far from a homogenous group, and according to historian Marie Claire Bergère, the composition of the group changed significantly in the first fifty years. Initially, Shanghai attracted foreigners who were focused on economic gain. However, many of the more transient, less invested groups left Shanghai toward the end of the 19 th century. ${ }^{6}$ In their place came people who were not simply economically motivated, but also interested in living in China and setting down roots in Shanghai. This group of privileged foreigners began to feel an attachment to the port, and began calling themselves "Shanghailanders" and "Old Shanghai Hands,"” terms still used today by foreign expats living in China. Amongst all of the groups, British were the the most influential; they held the most seats on the Shanghai Municipal Council, and made up $40 \%$ of the 643 foreign-run businesses in Shanghai in $1911 .{ }^{8}$ Foreign life was painstakingly modeled upon Western centers of cultural and political influence. In the 1860s young men would arrive alone, living

\footnotetext{
${ }^{5}$ Leo Ou-fan Lee, "Shanghai Modern: Reflections on Urban Culture in China in the 1930's." In Alternative Modernities, edited by Gaonkar, Dilip Parameshwar. (Durham, NC: Duke University Press, 2001), 119.

${ }^{6}$ Bergère, Shanghai, 85.

${ }^{7}$ Ibid.

${ }^{8}$ Ibid., 85-86.
} 
in communal quarters belonging to their employer. ${ }^{9}$ In the early 20th century more and more foreigners brought their wives and children with them to Shanghai, settling in houses they built themselves. With domestic duties relegated to Chinese servants, women took an active role in the social life of the concessions alongside their husbands. ${ }^{10}$

\section{Chinese in Shanghai}

The Taiping Rebellion (1850-1864) has been called the bloodiest civil war of the 19th century; it is estimated that over 20 million people died as a result of this war. ${ }^{11}$ In 1853, before the war reached Shanghai, only 500 Chinese lived in the Foreign Concessions, though they lived there illegally as laws by both foreign and Chinese authorities prohibited mixing. ${ }^{12}$ Before the Taiping Rebellion, large homes and lush gardens of foreign merchants characterized the urban fabric of the Concessions.

However, when Chinese refugees arrived from the countryside in search of a place to stay, laws governing segregation were quickly ignored by Western businessmen who saw an opportunity to turn a profit. Although, at first, authorities attempted to expel the new arrivals they ultimately failed in the face of resistance from both Chinese who were determined to find safety and security, and Westerners whose interest in fortune outweighed any other reservations they may have had. ${ }^{13}$ One foreign landlord explained his position to Sir Rutherford Alcock, member of the Shanghai Municipal Council:

In what way am I and my brother landholders and speculators concerned [by the

\footnotetext{
${ }^{9}$ Ibid., 93.

${ }^{10}$ lbid., 94.

${ }^{11}$ W. Scott Morton and Charlton M. Lewis. China : Its History and Culture. 4th ed. (New York: McGraw-Hill, 2005), 157-159.

${ }^{12}$ Hanchao Lu, "Away from Nanking Road: Small Stores and Neighborhood Life in Modern Shanghai." The Journal for Asiatic Studies 54, no. 1 (1995), 94.; Samuel Y. Liang, "Where the Courtyard Meets the Street: Spatial Culture of the Li Neighborhoods, Shanghai, 1870-1900." Journal of the Society of Architectural Historians 67, no. 4 (December, 2008): 482.

${ }^{13}$ Bergère, Shanghai, 44.
} 
risks of cohabitation]? It is my business to make a fortune with the least possible loss of time, by letting my land to Chinese, and building for them at thirty or forty per cent. [sic] interest, if that is the best thing I can do with my money. In two or three years at farthest, I hope to realize a fortune and get away; and what can it matter to me, if all Shanghai disappears afterwards, in fire or flood? ${ }^{14}$

Small rowhouses, called lilong, were built in between the massive mansions and villas of the foreign landowners. ${ }^{15}$ Landowners, especially eager to turn a profit, would sometimes even raze their own home to make room for lilongs. ${ }^{16}$

From September 1853 to July 1854 an initial wave of refugees from the Taiping Rebellion poured into Shanghai. Chinese from the neighboring Chinese walled city in Shanghai and the surrounding Jiangnan region flooded into the protected foreign concessions. This significantly changed the landscape of Shanghai. During this time, an estimated 20,000 Chinese sought refuge. ${ }^{17}$ And the number kept on growing; estimates of the Chinese population in the International Concessions by 1860 are around $110,000 .{ }^{18}$ By the turn of the century there were 345,276 Chinese living in the foreign concessions. ${ }^{19}$ The city grew westward, incorporating more and more land into the concessions. [Fig. 1.4] Many of these refugees decided to set down roots in Shanghai. Shanghai had grown from a gentile foreign port into a bustling, vibrant cosmopolitan city.

Many Chinese were drawn to Shanghai both because of the protection it offered as well as the opportunities it presented the traditionally overlooked merchant class. In Shanghai this group was not simply tolerated; here they found kindred spirits amongst the

\footnotetext{
${ }^{14}$ Carlos Augusto Montalto Jesus, Historic Shanghai. (Shanghai: The Shanghai Mercury, limited, 1909), 102.

${ }^{15}$ Liang, Where, 482.

${ }^{16}$ Bergère, Shanghai, 56-7.

${ }^{17}$ Lu, Away, 94.

${ }^{18}$ Liang, Where, 483.

19 Ibid.
} 
Western merchants and businessmen. ${ }^{20}$ The city provided new opportunities for Chinese and possibilities for change in society, culture and politics. The importance of trade and commerce in Shanghai disrupted the traditional Chinese occupational hierarchy (scholars, farmers, craftsmen, and at the bottom, merchants). ${ }^{21}$ For the first time in Chinese history wealthy merchants became élite and powerful members of society, an indication not only of a societal shift but also of an opportunity to achieve social success and gain power that must have appealed to merchants elsewhere in China.

Although the cost of living was much higher in Shanghai than other parts of China, more and more Chinese immigrants found that the benefits of greater social mobility and growing economic opportunity outweighed the disadvantage of cost. ${ }^{22}$ Confucian teachings of filial piety (which is tied to tiered state bureaucracy as much as familial ties), reverence for tradition, and scholarly learning were less relevant to the newly wealthy Chinese merchants who benefited from business and trade with the Westerners. According to historian Samuel Liang the foreign concessions created a place outside of the jurisdiction of mandarin rulers that was valued by Chinese sojourners. Here, merchants did not have to purchase gentry status to enjoy social recognition. Many started humbly, but by emulated foreign and Chinese merchants, expanding their trade and social influence and became part of the new elite class. ${ }^{23}$ After the civil unrest of the Taiping Rebellion

\footnotetext{
${ }^{20} \mathrm{lbid}$.

${ }^{21}$ John King Fairbank and Merle Goldman. China : A New History. 2 enl ed. (Cambridge, Mass.: Belknap Press of Harvard University Press, 2006), 42.

${ }^{22}$ Samuel Y. Liang, "Where the Courtyard Meets the Street: Spatial Culture of the Li Neighborhoods, Shanghai, 1870-1900." Journal of the Society of Architectural Historians 67, no. 4 (December, 2008, 2008): 494.

${ }^{23}$ Samuel Y. Liang, Mapping Modernity in Shanghai: Space, Gender, and Visual Culture in the Sojourners' City, 1853-98. (London; New York: Routledge, 2010) 24.
} 
abated, Shanghai attracted other groups, such as literati scholars, landowners, bankers, craftsmen and peasants. ${ }^{24}$ Half a century later Shanghai was home to the first Chinese industrialists and bourgeois. ${ }^{25}$

For the Chinese merchants, adhering to Western conventions, both in their social activities as well as the spaces they lived in, set them apart from other Chinese residents as a new self-consciously modern class. Status and identity for many merchant and banking families was tied to an openness to the West, and manifested in domestic spaces.

Historically, trade made China a powerful and wealthy country. Yet Confucian beliefs were intolerant not only of the merchant class, but also of any tawdry displays of wealth. However, Shanghai's success around the turn of the 20th century brought into sharp focus the important role merchants paid to the success of China. Shanghai merchants enjoyed social distinction, power and influence. ${ }^{26}$ This rejection of Confucian values should be considered an incredible moment of change for China since Confucian beliefs and rituals were the foundations of both the political and religious realms of Chinese society and culture since the 6 th century B.C. ${ }^{27}$

From the late 1890s onwards Shanghai drew wealthy Chinese and foreigners seeking better living conditions, more accessible daily shopping, and greater range of theaters, retail shopping, and other forms of entertainment. ${ }^{28}$ Chinese merchants followed their middle class patrons outside of the old Chinese city walls, relocating branches of their

\footnotetext{
${ }^{24}$ Bergère, Shanghai, 99.

${ }^{25}$ Liang, Mapping Modernity, 24.

${ }^{26}$ Bergère, Shanghai, 252.; Lu, Away, 173.

${ }^{27}$ Donald S. Lopez, Religions of China in Practice. (Princeton, N.J.: Princeton University Press), 1996.

${ }^{28}$ Liang, Where, 485.
} 
business to the foreign settlements. ${ }^{29}$

By the first decade of the 20th century Shanghai was an acceptable and desirable city in which to live for foreign and Chinese families. It had grown from a bustling port of trade into a large metropolitan capital with churches, appropriate schools for foreign children, newspapers, and municipal services such as electricity and running water. Shanghai also offered a range of modern entertainments and amenities to support a vibrant social scene; theaters and ballrooms, cafes, department stores, elite social clubs, and even a race track and canidrome.

Originally there were few architects in Shanghai, and building in Western styles was more challenging for unskilled laborers, and more costly, than in the West. Yet when Westerners came to Shanghai they built homes in foreign styles or prefered to move into Western apartments and townhouses. The noble foreign trade houses and banks along the Bund were almost entirely built in Western styles. Homes similarly recalled architectural fashions found in the West.

Western architectural education for Chinese began at the turn of the 20th century as young students left China to study architecture in America, Europe, and Australia. These early students returned to China and worked in the offices of Western architects who had already established practices in China, such as the Yale-educated architect Henry K. Murphy. ${ }^{30}$ By the 1920's and 1930's the majority of Chinese architects practicing in China had been educated in the Beaux Arts method in America, often at the University of

\footnotetext{
${ }^{29}$ Brenda Sternquist and Yan Ma. "Department Stores in Early 20th Century Shanghai; Embeddedness of Clan Structure in the Business Environment." Article. 342.

${ }^{30}$ Xing Ruan, "Accidental Affinities: American Beaux Arts Architecture in Twentieth Century Chinese Education and Architectural Practice." Journal of the Society of Architectural Historians 61, no. 1 (2002), 30-31.
} 
Pennsylvania. ${ }^{31}$

Living close together meant that, for the first time in history, Westerners and the Chinese could learn about each other's daily life. Foreign residents constructed a racetrack, movie theaters, bars and coffee houses which soon became familiar to the Chinese of Shanghai. ${ }^{32}$ In the early 20th century consumerism and the luxurious lifestyle it promoted became linked to modern living. And Shanghai developed a consumer culture that integrated recreation, socialization, consumerism, and luxury.

Internationally, Shanghai became known as a modern city, drawing interest from foreigners and Chinese. By the 1920's and 1930's Chinese students returning from studying in the West were drawn to Shanghai's modern conveniences and cosmopolitan lifestyle. By 1933 the population totaled over 3 million people, of which about half were Chinese, and 70,000 were Westerners. ${ }^{33}$ The population was centered around the foreign concessions. [Figures 1.5 and 1.6] Shanghai residents could enjoy everything from the convenience of streetcars and automobiles, the latest fashions from Paris and Milan on display at the Nanjing Road department stores, and the social buzz of innumerable jazz clubs, rooftop gardens atop skyscrapers, and European style cafes. ${ }^{34}$ These attractions became alternatives to the traditional Chinese urban spaces such as tea houses, local restaurants, and opera houses. They became a familiar background seen in the works Shanghai's artists and writers, and a stomping ground for the middle class Chinese and

\footnotetext{
${ }^{31}$ lbid., 31.

${ }^{32}$ Lee, Shanghai Modern: The Flowering of a New Urban Culture in China, 17.

${ }^{33}$ Lee, "Shanghai Modern: Reflections on Urban Culture in China in the 1930's," 119.

${ }^{34}$ Lenore Hietkamp, Laszlo Hudec and the Park Hotel in Shanghai. (Shawnigan Lake, BC: Diamond River Book, 2012) 7.
} 
foreigners alike. ${ }^{35}$

Shanghai developed as a city where boundaries separating the Chinese and foreign communities were quickly dissolved, neighborhoods were mixed, and traditional expectations of ethnic segregation were upended. Historians often discuss the lilong communities as if they were islands of Chinese-ness, and the foreign villas and apartments islands of foreign-ness. Separating the communities into such distinct spheres is problematic, constructing a Shanghai that is defined by rigid boundaries. These histories are disputed by first hand accounts of many Shanghai residents as well as the city directories. In fact, the majority of the urban fabric of Shanghai was mixed, with villas, lilongs, apartment buildings abutting cinemas, hotels, and department stores. The city's population was dense and the urban fabric far from segregated by ethnicity. ${ }^{36}$ Many neighborhoods have been described by scholars (Lu, Liang, Hammond, Meng, Lee) as distinct and tightly knit communities of Chinese. A tight-knit community does not necessarily indicate that they were segregated. With evidence of children attending school with children of all nationalities, the need for both Chinese and foreign workers in any large successful office operating on Chinese soil, and the fact that the lilongs were located within the "foreign" concessions, assumptions of a rigid cleavage evoked by a Chinese/foreign duality are called into question. This is not to suggest that Shanghai was more tolerant or integrated, only that people necessarily came into contact and that neighborhoods were far from stratified ethnic enclaves. Interactions were as inevitable as they were constant. ${ }^{37}$

\footnotetext{
${ }^{35}$ Lee, Shanghai Modern: The Flowering of a New Urban Culture in China, 38.

${ }^{36}$ Lee, Shanghai Modern: The Flowering of a New Urban Culture in China, 33.

${ }^{37}$ Later Shanghai history also calls into question the binary of foreign/Chinese representation of Shanghai. The number of foreign residents in Shanghai increased during the Second World War. Shanghai was the last open port of harbor for European refugees, and did not require official papers. In the documentary Shanghai
} 


\section{State of the Field}

Since China's reopening in the late 1980's and early 90's, Shanghai has been rediscovered by historians in the East and West. Concerning the built environment, there are many histories aimed at non-academics, non-specialists: books, museums exhibitions and articles. These histories often focus on the grand architecture of the Bund or other scenic areas of the city.

Specialists in architecture, gender studies, urban studies and Asian studies are revisioning Shanghai history as a dynamic, complicated terrain. Often these academicians focus on gender, film, the vernacular architecture of a region, and the everyday public spaces that emerged at the end of the 19th century in Shanghai. These sources interweave disciplines, assuming a vertically integrated terrain of humanities discourses is critical to the best understanding of any history. They also tend to focus on specific places within the city as case studies for their academic exploration. Yue Meng's 2006 publication, Shanghai and the Edges of Empires, repositions Shanghai as a city whose success is due not to the foreign enclaves acting upon an impotent city, but rather to a variety of discrete events that took place in China, and specifically events in the the Jiangnan region. Histories treating the early development of modern Shanghai, such as Samuel Y. Liang's Mapping Modernity in Shanghai; Space gender and visual culture in

\footnotetext{
Exodus, two now-elderly European brothers are followed on a visit to their childhood home during World War II, in a meandering Shanghai lilong. We can conjecture that many of the European refugees, arriving with few possessions and little money, would have made a lilong house their home in Shanghai. This information challenges current accounts of Shanghai, which represent the city from different perspectives based upon race and class, as if the people inhabited different cities altogether. Tess Johnston and Dongqiang Er. Frenchtown Shanghai : Western Architecture in Shanghai's Old French Concession. 1st ed. Hong Kong: Old China Hand Press, 2000.; Catherine Vance Yeh, "The Life-Style of Four Wenren in Late Qing Shanghai." Harvard Journal of Asiatic Studies, Vol. 57, No. 2. Harvard-Yenching Institute. (1997) 426
} 
the sojourner's city, 1853-98, suggest the wealth of information provided by interdisciplinary sources that focus on urban public history. Liang looks closely at merchant residences, houses of courtesans, public spaces of celebration, streetscapes such as the Bund, markets and Fourth Avenue, pinpointing spaces of social and gender relations as key to the modernization process. Mapping Modernity argues that a reconfiguration of the urban everyday spaces of life led to modernization of Shanghai in the mid-1800s. Other books that focus on the varied social terrain include Hanchao Lu's Beyond the Neon Lights: Everyday Shanghai in the Early Twentieth Century. In this work he focuses on alleyway-house neighborhoods which developed around Shanghai in response to the housing needs of poorer workers such as rickshaw men and factory workers. Finally, in looking at these urban spaces these writers engage in deeper analysis of social relations to fully understand and analyze the import of the structure. At the forefront of discussions about the development of modern urban spaces in Shanghai are scholars of gender studies, cultural studies and Asian studies.

The methodologies of these scholars does not include formal analysis of the built environment, rather they draw upon literature, newspapers, and lithographs broad understanding of the dynamic urban spaces of the city and how it has been used by its inhabitants. The majority engage with larger theoretical discourses, including the work of Lefebvre, Benjamin and others in critical studies. In these accounts the built environment is interpreted and recast as a crucible for the modern lives of Shanghai city dwellers.

Few architectural historians write about the work of individual architects or, focus on specific buildings. Recently, Lenore Hietkamp wrote about architect Laszlo Hudec's in 
Laszlo Hudec and the Park Hotel in Shanghai. Historian Jeffrey Cody researched American architect Henry K. Murphy's architectural practice for Building in China: Henry K. Murphy's "Adaptive Architecture", some of which took place in Shanghai. These historians analyze controlling visions of iconography and style exercised by a patron or architect in tandem with biographical information that informs their practice and commissions.

The history of Shanghai's domestic architecture has been passed over by Western scholarship. Rather, an avid group of largely-expat preservationists lead by University of Virginia alumna Tess Johnston and the influential Shanghai photographer Deke Erh (爾冬 強) have written a variety of different books published by their own print house, documenting the quickly disappearing domestic and Western architecture of Shanghai. Johnston and Erh are the most prolific of these preservationists, having published more than twenty books. While neither Johnston nor Erh are trained historians, their work shows a high level of sophistication and care in presenting and documenting each building. Their books combine vibrant photographs of the exterior and interior of buildings with oral histories, archival photographs, maps, city directories and other records from the municipal governments. If possible, information about who constructed or commissioned each building is included along with biographical information.

This thesis will consider the role domestic architecture played in the negotiation of identity, class, and culture in Shanghai. By building upon the work in the field of critical studies the images, symbols, and metaphors of domestic architecture can be explored. In turn, Shanghai villas built between in 1920's and 1930's provide case studies that can be 
deconstructed as text. [Fig. 1.7] The visual understanding of domestic spaces that responded to varied ideas about culture, class, and identity lay rooted as much in an easily translatable visual and stylistic vocabulary as in the willingness of the viewer to accept the interpretation laid before them. 


\section{Negotiating Identity, Class, and Culture}

This chapter discusses domestic spaces, identity, and cultural production through the work of critical theorists. A constellation of theoretical positions sets the stage for subsequent case studies, allowing us to consider Shanghai as a text and cultural

monument, and to discuss Shanghai's symbolic representation in terms of negotiations of identity, culture, and class.

From the late 19th and into the 20th century Shanghai was an acceptable and desirable city in which to live for foreign and Chinese families. It had grown from a bustling port of trade into a large metropolitan capital with churches, appropriate schools for foreign children, newspapers, and municipal services such as electricity and running water. Shanghai also offered a range of modern entertainments and amenities to support a vibrant social scene; theaters and ballrooms, cafes, department stores, elite social clubs, and even a race track and canidrome.

Negotiations are a constantly present and fluid element of visual styles as common to Europe and America as they are to China. During the early 20th Century China was searching for a style appropriate to post-Qing political, cultural and social aspirations. In Shanghai as in the West, these negotiations were enacted in the built environment, and took many different forms. For the architecture of the Bund, a prominent Shanghai waterfront business district and the original gateway to the city, architects such as Palmer and Turner looked to time-tested Western styles to provide a gravitas and timeless sophistication befitting a company's prominent position in the international business world. The architects of the British and American Customs House for example, searching for a 
powerful symbol of extraterritorial influence for the high central tower, copied the face of Big Ben, the famous clock surmounting Westminster palace in London. The Hong Kong Shanghai Bank of China (HSBC) rebuilt their compound at the turn of the 20th century. The new building, designed by Palmer and Turner, was a massive Neoclassical edifice that stretched for an entire block. It was heavily ornamented, and included two bronze lions by British sculptor Henry Poole, and keystones carved to represent agriculture, industry, and shipping. At the center of the facade below an ionic colonnade three archways lead from the rusticated ground floor into the central domed entry way of the building. The dome amplified the sense of the buildings prominence on the exterior, and was decorated with a stunning marble mosaic on the interior. Either of these buildings would be at home in a major Western capital city as they were in Shanghai. In terms of negotiation, these buildings are just two in a wide span of visual choices. This fluidity of meanings and associations speak to the various aspirations of the architects and clients in distinct ways.

\section{Culture}

In order for negotiations in the constructed environment to be successful, they must employ a visual vocabulary that can be read and understood by not only the patron and architect, but also others living in Shanghai. Both the individual and their intended audience must possess a shared understanding of culture. In Shanghai, European revival typologies were the most popular form of cultural expression in domestic architecture. What culture was it? What ideals of culture are bound in these typologies? The question of architecture's relation to culture is itself dependent on an understanding of the assumptions of the term culture. 
A reified historical viewshed informs architectural styles of the Shanghai domestic sphere. Homi K. Bhabha discusses the problems with presenting a stable, knowable culture in his consideration of cultural diversity and cultural difference. ${ }^{38}$ In "Cultural Diversity and Cultural Differences," Bhabha underscores that historical culture is often reflected and presented to bolster authority rather than authenticity. For Bhabha, cultural difference is an understanding of culture as an empirical, measurable knowledge. Bhabha asserts that cultural critics look at the boundaries between cultures to examine cultural questions of difference and diversity. In this liminal space differences can be seen, however boundaries are problematic spaces that often lead to the misunderstandings of meaning, values and signs. Our perspective is thus limited, and so Bhabha's argues that we must enter into a "Third Space" in which we can look at ourselves, giving us the ability to overcome these issues. The boundaries of a reified culture problematize interpretation and understanding of that culture, yet an understanding of how architectural style was intended must acknowledge an understanding based upon these same boundaries.

Shanghai is an incredibly dynamic space. As a cosmopolitan urban center that simultaneously experienced rapid growth and a large influx of Chinese and foreign citizens, it would be easy to cling to an understanding of the city that is represented by different cultures; foreign and Chinese, modern and traditional. In fact, this tacit assumption of a reified culture is shared by many sinologists. While this perception of uncompromised purity might be helpful in understanding motivations for using a particular architectural typology, is culture anything more than an unachievable myth? In the essay, "Toward a

\footnotetext{
${ }^{38}$ Homi K. Bhabha, "Cultural Diversity and Cultural Differences," The Post-Colonial Studies Reader, ed. B. Ashcroft, G. Griffiths, H. Tiffin (Routledge, New York 2006), 155-157, 208.
} 
theory of the Intercultural," Jonathan Hay's delineation between culture and cultural/intercultural develops this distinction. The intercultural describes the constitutively hybrid nature of any given culture. The cultural (adj) is "the realm of differences, contrasts, comparisons... the dynamic that exists between group identities and internally differentiated formal structure of cultural practices within their self-consciously maintained professional and craft traditions." ${ }^{39}$ Hay asserts that culture $(n)$ is a static fixing of the dynamic word cultural (adj). Culture implies coherent ethnic, moral, and historical borders that can be policed by those individuals who feel they have ownership over said culture. Historians must be able to delineate between the idealized, mythologized culture of a distant and elite past represented by revival styles, versus the moments of connection, translation, or reflection between various groups in Shanghai. In short, on the one hand we have myth, on the other we have practice. Both of these concepts allow a more coherent understanding of the negotiations that marked the Shanghai domestic sphere.

Architectural styles in Shanghai were moulded to fit both the resources at hand as well as the needs of the individual, from responding to local climatic differences to accommodating Chinese style kitchens. The adaptation and reinvention of Western forms evidences rich cross-cultural exchanges. Historian Frank Dikötter argues persuasively that especially in Republican Era China (1911-1937) the entire country experienced a curiosity about the world outside of their community. China made efforts to open up its borders, minds and markets during this diverse and cosmopolitan period. ${ }^{40}$ Though the historic

\footnotetext{
39 Jonathan Hay,"Towards a Theory of the Intercultural. RES: Anthropology and Aesthetics no. 35, Intercultural China (Spring, 1999): 5-9. http://www.jstor.org/stable/20167015. 5.

${ }^{40}$ Frank Dikötter, The Age of Openness : China before Mao. (Berkeley: University of California Press, 2008), 3.
} 
landscape was influenced by Western culture introduced by foreigners living in Shanghai and Chinese who traveled for business and educational opportunities, many recent historians persuasively argue that Western culture was not the sole prophet of modernity that some teleological accounts describe. ${ }^{41}$ Rather, it was the confluence of Shanghai residents, both Western and Chinese, who created new hybrid spaces that were able to accommodate a myriad of intercultural influences.

\section{Myth and Narrative}

Building upon this understanding of the the individuals living in Shanghai, theories of myth and narrative allow us to uncover the sediments of various negotiations of culture, identity, and class. These complex and at times intersecting layers also converge with the myths and narratives present in the architectural fabric. Theories of myth and image making support a close reading of negotiations of power, identity, culture, and community in Shanghai vis-a-vis the built environment. This necessitates an understanding of the language of architecture, so that the built environment can speak.

Interpreting negotiations necessitates a vantagepoint from which the historian can understand the mythology of a specific home situated in a larger constellation of cultural productions. In The Way of the Masks Claude Levi Strauss sets out to demonstrate, through a case study, that plastic art objects cannot be understood in isolation, rather their meaning is relational. As with myths, masks must be returned to their transformative set: the set of masks and their associated myths within each echoes and transforms the others. ${ }^{42}$ Similarly, domestic architecture in Shanghai is relational, and loses meaning when

\footnotetext{
41 Meng, 2006; Liang, 2010; Lu, 1992; Bergere, 2009.

42 Claude Lévi-Strauss, The Way of the Masks [Voie des masques. English. 1982]. (Seattle: University of Washington Press, 1982), 12.
} 
considered in isolation. The historical and (inter)cultural context must be understood. This is accomplished by establishing it's relation to a set of related historical viewsheds and cultural exchanges is critical to understanding it. Like masks, architecture is entangled with myths; nostalgic historic viewsheds such as the Colonial Revival, the moral ethos of the Arts and Crafts, the historical and cultural sway of palladian architectural styles. The cultural context in which a style is rooted illuminates dialogue between architectural typologies, in which a typology responds to and/or asserts itself in contrast to others.

This relational understanding of the built environment allows for a nuanced, layered approach to the urban fabric wherein architecture is an utterance of culture, of class, of identity. Modernity, national identity, class, and culture are bound in the stylistic strategies of a building.

As architecture changes contexts or owner, all past owners and contexts are transmitted along with it. Meaning must be maintained. Architecture is thus imbued with history, not only the history of their own making and being, but the history of all other architectures, cultures and of contexts. In this way, the architecture of Shanghai recalls the words of Walter Benjamin:

"There is no document of civilization which is not at the same time a document of barbarism. And just as such a document is not free of barbarism, barbarism taints also the manner in which it was transmitted from one owner to another." ${ }^{43}$

Shanghai revival architecture can be read as a valuation of the past and of the primacy and legitimacy of specific cultural viewsheds, especially buildings that evoke extra-local sources of history or heritage. History is a base upon which societies build, carving out

\footnotetext{
${ }^{43}$ Walter Benjamin and Hannah Arendt. Illuminations [Illuminationen. English]. (New York: Schocken Books, 1986) VIII.
} 
understandings of ourselves and the past that are necessarily in opposition to the other.

The architecture of Shanghai is also a commentary on cultural value that is hierarchical and biased.

Theorist Xudong Zhang argues that Shanghai produces an intricate network of signs, narratives, and images. Thus, Shanghai becomes a living creature who is understood through its imagery and the associated mythologies. A critical reading is accomplished by an understanding of the city's politics, and the way in which it becomes a "sensuous abstraction" that captures its own image, materiality, and its self-adoration. ${ }^{44}$ One reading of the Western architectural typologies evidences a symbolic relationship with Western centers of power. Some links with heritage are so direct that there is no question as to their intentions. One example is the home of Cornell Franklin, a wealthy American judge from Mississippi. Judge Franklin built a lavish mansion in the heart of the French Concession modeled after Washington's Mount Vernon. This is an unequivocal link with American Colonial Revival typologies, and more importantly, the beloved home of America's most cherished Founding Father, George Washington. The Franklins aligned themselves with the evocative narrative of the Colonial Revival, a lineage of great American political leaders, and though their house may have been in the French Concession, they placed themselves well within the borders of an American hegemony. The nature of this documentation aggressively asserts a primacy of culture and politics. The stakes of negotiations were high: whereas for Westerners these negotiations could be seen as continuity with their heritage, for Chinese aligning oneself with another

\footnotetext{
${ }^{44}$ Xudong Zhang, "Shanghai Image: Critical Iconography, Minor Literature, and the Un-Making of a Modern Chinese Mythology”, New Literary History 33, no. 1, 2002, 144.
} 
culture meant aligning oneself with the "other" in direct opposition to the high culture of

Beijing. ${ }^{45}$ In this way the urban sphere was witness to the emergence of a new class of elite Chinese merchants who were asserting the primacy of their new culture and shedding the constraints of traditional Chinese society. By embracing newly imported Western forms they were also embracing Shanghai's modern, cosmopolitan spirit and aligning themselves with the worldliness, momentum and prosperity of the time.

\section{Domesticity and the Home}

Culture, the reified term that connotates ownership and clear cut boundaries, is a concept important to theories of the domestic sphere in the late 19th and early 20th century. In the domestic sphere, symbolic expressions about concepts like function or family can be explored at the individual level. Here, in the home, the architect and patron explore their personal visions. Will they challenge or refine the society in which they are living by drawing on familiar sources or departing from them in favor of something new? Domestic design can thus make statements about culture and the cultural.

Cultural views on domesticity from the early 20th century often position the home in an ideological battle. The home becomes an affirmation of the values of its inhabitants.

This was no less true for Chinese, who placed great valued on the domestic sphere.

Domestic spaces not only influenced the family environment, and the shaping of personal moral character were part of an equation that could lead to the success of demise of one's family. ${ }^{46}$ The domestic sphere provided the family with a space to prepare their children

\footnotetext{
${ }^{45}$ Bergère, Shanghai, 243.

${ }^{46}$ For more about the intersection of morality and the domestic sphere in America, see Gwendolyn Wright, Moralism and the Model Home, Domestic Architecture and Cultural Conflict in Chicago, 1873-1913.

(Chicago: University of Chicago Press, 1980.);
} 
for participation in the public sphere, a place to reinforce civic and religious values.

Shanghai homes were where domestic ideals were manifested, but also the stage for a visual rhetoric that emphasized exclusion and superiority. Elite homes were surrounded by high walls which separated them from the streets, and typically featured larger lots for increased privacy. Interiors and exteriors of Shanghai homes were largely inspired by popular Western architectural typologies, at once giving preference to contemporary architectural trends in distant cultural centers, and also tacitly aligning occupants with specific cultural viewsheds. This reinforced a separation between the elite from the poor and middle class.

Shanghai's urban dwellers relied upon multiple layers of meaning during these negotiations, which reflected the needs of the individual or group in question. The intentions of a revival style would be much different depending upon the client's nationality and cultural connections. Contending for meaning in this cosmopolitan sphere is tied to an understanding of who built or lived in each space.

For example, a style such as the Tudor, a revival style originating in England that was widely used in domestic architecture in Shanghai becomes more than an aesthetic choice. The Tudor house embodies a history and culture rooted in British soil, that is understood as something pure and quantifiable that represents the values of those who live in the house. It allows the family to signal their distinct culture, and in the context of Shanghai, extend it to foreign soil. The importation of these domestic forms and their perceived unity with Western culture is entangled with negotiations of legitimacy of each country/individual's authority in relation to culture. Seen as a whole these typologies 
represent a carefully codified language that continues to reinforce layers of negotiation bound in a Western/otherness. Homes built in contemporary styles, such as Streamline Moderne, are more flexible in their ability to incorporate elements of different cultural traditions into a cohesive whole; they reflect the desire to forge a new or different path ahead.

Thus, negotiations are evidenced in intricate layers of meaning. The constant interplay of these layers, which is fluid rather than rigidly prescribed, is a critical component of their implementation. Similarly, the symbolic representations of culture embedded in architectural styles found in Shanghai are best understood when seen in relation with one another. The styles signal information about the patron (and the architect), and are important forms of narrative and image making for Shanghai residents. These representations can also be seen as in dialogue with one another; for instance the contrast between the grand architecture of international banks on the Bund versus the more homely and domestic Tudor along Columbia Circle. These layers of negotiation are not only found in the domestic sphere, but also in the many cultural spheres that intersect with it; fashion, art, architecture, language, writing, and media. Moreover, in Shanghai the use of heritage/revival styles seems to evidence a continuity of cultural viewsheds that has transnational implications. The legacy of the distant metropole is extended to its fringes, with Shanghai's architects and their wealthy clients as the evangelizing force. 


\section{The Franklin Mansion}

The Franklin Mansion provides a case study of the American Colonial Revival, demonstrating the transnational fluency of what has often been considered a national architectural idiom.

The popularity of the American Colonial Revival is a complicated narrative that spans the centuries since the founding of America. As early as the 1770's, images celebrating and mythologizing the American past have dominated America's cultural and historical viewshed. Colonial Revival architecture is popular coast to coast in countless imaginative and inventive iterations. However, it is not a style or typology, but rather a way of looking at the past. Inspiration might be drawn from many diverse sources united by a common theme: the celebration of a nostalgic form of American history and culture. ${ }^{47}$ The movement was part of a search for identity that was common to many countries in the 18th and 19th century, who looked for a national historic viewshed to inform their arts and architecture ${ }^{48}$ Americans drew upon early historical subjects related to the country's founding, as well as to the country's pristine and awe-inspiring natural features.

What happens when this particular architectural idiom surfaces in an American territory? In Shanghai, the Colonial Revival becomes a transnational style advertising the nationality, wealth and status of its occupant. It is both an assertion of American values and culture and also, a stylish mode of domestic architecture that sentimentally recalls hearth

\footnotetext{
${ }^{47}$ Richard Guy Wilson, Shaun Eyring, and Kenny Marotta. Re-Creating the American Past: Essays on the Colonial Revival. (Charlottesville; London: University of Virginia Press, 2006), 1-5.

${ }^{48}$ The Tudor and French Revival homes discussed in subsequent chapters are also related to this search for an appropriate national identity.
} 
and home.

In some iterations of the Colonial Revival, the founding fathers were a favored subject. They embodied pure political ideals and their lives were held up as moral guides for the American family. In the years after his death, Washington gained historical recognition as the greatest of all founding fathers. The life of Washington was a favored subject for the American colonial revival, from poems to paintings. Many saw in Washington a symbol of union that encompassed the family, home and country in a single ideal. ${ }^{49}$ His house, Mount Vernon, was reproduced in popular prints, becoming an icon during his lifetime. ${ }^{50}$ It was also the focus of the first historic preservation battle in the United States fought by the Mount Vernon Ladies' Association in the 1850's. ${ }^{51}$ Replicas of Mount Vernon appeared in elsewhere in America. Mount Vernon was renamed "The Jefferson" in the prefabricated housing catalogues of Sears Roebuck and Co., a copy of Washington's home selling for $\$ 3,350$ in $1932 .{ }^{52}$ Six replicas of Mount Vernon were also built for World's Fairs and Centennial Exhibitions between 1893 and 1934, including an appearance in France in $1931 .^{53}$

\section{Franklin Mansion}

Upon viewing the Franklin mansion there was to be no mistake about the nationality

\footnotetext{
49 Joseph Michael Sommers, "Godey's Lady's Book: Sarah Hale and the Construction of Sentimental Nationalism." College Literature 37, no. 3 (2010), 44.

${ }^{50}$ Lydia Mattice Brandt, "Re-Living Mount Vernon: Replicas and Memories of America's most Famous House." (PhD, University of Virginia, 2011), 18.

51 To learn more about the history of the battle to save Mount Vernon and the Mount Vernon Ladies' Association of the Union see: Emma R. Ball, Washington's Home and the Story of the Mount Vernon Ladies' Association of the Union. Richmond: Whittet \& Shepperson, (1912).; Stephen A. McLeod, and Carol Borchert Cadou. The Mount Vernon Ladies' Association: 150 Years of Restoring George Washington's Home. Mount Vernon, Va.: Mount Vernon Ladies' Association, (2010).

52 Sears, Roebuck \&. Co. Homes of Today (Sears, Roebuck \& Co, 1932) 30.

${ }^{53}$ Brandt, Re-living Mount Vernon, 15.
} 
of its owners, Americans' Judge Cornell S. Franklin and his wife, Estelle Oldham. (Estelle is shown in Fig. 3.1 with their son in Shanghai.) Their Colonial Revival mansion, built circa 1925, was described as decidedly antebellum, recalling both their Mississippi origins and, more generally, their American heritage.$^{54}$ [Fig. 3.2 and 3.3] The Franklins built their home on Avenue Joffre (now 338 Huaihai Road), a chic neighborhood within the French Concession. Their house, one of only a few built in the American colonial revival style in Shanghai, borrows the rhythms, massing and motifs from Mount Vernon. [Fig. 3.4] The sumptuous mansion's exterior features a deep two story portico that is supported by elegant, elongated tuscan columns arranged in five bays. Although the building does not include a central cupola or spire, it still mimics the roofline of Mount Vernon in the incorporation of two large chimneys and three evenly spaced dormer windows. The entryway has been modified, and features a grand central doorway under the portico surmounted by a palladian window. Similar to other iterations of Mount Vernon, the Franklin Mansion does not have the two wings, rather it retains only the central building. It was originally sited in the center of a large property, and reached by a long driveway.

Today the house is owned by the People's Liberation Army, and houses a hospital, making it off-limits to visitors. ${ }^{55}$ The few photos of the current interior show original interiors and decorative motifs. These include the centerpiece of many an American home: a large hearth (now covered) framed by attached fluted pilasters. [Fig. 3.5] Georgian detailing is used throughout, from the cornices and wainscoting to the use of large triangular Georgian pediments surmounting doorways. [Fig. 3.6] It is likely these would have disappeared were

\footnotetext{
${ }^{54}$ Tess Johnston and Dongqiang Er. Frenchtown Shanghai : Western Architecture in Shanghai's Old French Concession. 1st ed. (Hong Kong: Old China Hand Press, 2000), 80-82.

${ }^{55}$ Cranley, Shanghailanders, 111.
} 
the villa, like the majority of Shanghai mansions, divided and given over to multiple family habitation in the 1950's.

An article in Time entitled, "China: Cultivated Lands" describes the house as much as it does their lifestyle.

A good sport and a fighting gentleman, Cornell Franklin has transplanted the South—mint juleps, hunting dogs, polo, a white house with a proper portico—right to cosmopolitan Shanghai. ${ }^{56}$

This house was built to showcase the Franklin's wealth and national identity to any who came to visit. Like many other mansions in expatriate Shanghai, the mansion was suitably outfitted to entertain friends and visiting figures, as described by biographer Joseph Leo Blotner:

[Estelle] and Cornell lived the active life of the international set's upper echelon. In Shanghai, there were the dances, the parties, the games of mah-jongg for high stakes, but it was a life that could pall. Cornell was charming and now distinguished, and his business and social calendars were always full. He liked to drink and he liked to gamble. So did Estelle. There was a full staff to take care of running the house and entertaining. But in spite of the children, in spite of all the activities they shared, there was a process of distancing... ${ }^{57}$

In the late 1920's Estelle and Cornell's marriage ended and Estelle returned to Mississippi. Soon after returning, Estelle Oldham married William Faulkner. ${ }^{58}$ Cornell went on to remarry, was an active member of many of the elite Shanghai men's clubs, and noted in Men of Shanghai and North China.${ }^{59}$ Likewise, his career was notable; he moved up from judge to eventually serve as Chairman of the Municipal Council, the head of the

\footnotetext{
56 "China: Cultivated Lands." Time 35, no. 11 (3/11, 1940).

57 Joseph Leo Blotner, Faulkner : A Biography. One-volume , 1 ed. (New York: Random House, 1984), 124-25.

${ }^{58}$ Blotner, Faulkner, 239.

${ }^{59}$ Patrick Cranley, et al. Shanghailanders and Shanghainese: Where they Lived, Worked, and Played; Still More Shanghai Walks. Shanghai Walks. Vol. 1. (Hong Kong and Shanghai: Old China Hand Press, 2011), 111.
} 
International Settlement from 1937-1941. ${ }^{60}$

Since the early 1800's Mount Vernon had been an historic pilgrimage site for American and international tourists. ${ }^{61}$ There is no doubt that the Franklins modeled their home deliberately after Mount Vernon, which was world famous by the 1920's, having been a feature of countless 19th century guidebooks, written about in newspapers and magazines, and its image replicated in paintings and souvenir prints. It was rebuilt in its entirety time and time again to represent the state of Virginia or even the United States at World's Fairs. ${ }^{62}$

As a public servant with grand political aspirations, Cornell Franklin would have benefited from the connection to America's founding father. The importance of a connection to Washington lies in an understanding of Washington's life. Washington was perceived as a noble American leader. When called to military duty Washington served his country and when his battles were won, he returned peacefully to his farm. Later, Washington reluctantly returned to serve his country again as the first president. In his sacrifice of personal interests to selflessly assume the burden of civic responsibility, coupled with a humble return to private life, Washington epitomized public virtue and republican citizenship. ${ }^{63}$ What more appropriate figure could Cornell Franklin have chosen to model himself after in Shanghai? In his imitation of Washington, Franklin asserts his political and career ambitions. Without question, seeing Mount Vernon in Shanghai evoked an idealistic and nostalgic American patriotism.

\footnotetext{
${ }^{60}$ Cranley, Shanghailanders, 111.

${ }^{61}$ Brandt, Re-living Mount Vernon, 36.

62 Brandt, Re-living Mount Vernon, 38-41,

${ }^{63}$ Brandt, Re-living Mount Vernon, 29.
} 
In addition to the connection to a selfless public servant, Mount Vernon also became associated with American domestic ideals and a reified construction of culture. During the 19th century the home was believed to impart Christian values and mold the character of the family who lived in it. Domestic life was linked to civic duty, Christian morality, and patriotism. As the most revered founding father, the example of Washington's family life at Mount Vernon provided a model for many Americans. The domestic ideal of Mount Vernon and its moralizing implications was the subject of many well known 19th century historians, such as John Frost, and provided inspiration for painters, such as Junius Brutus Stearns.

By drawing upon one of the most powerful images of the colonial revival, the Franklins aligned themselves with political sacrifice and moral duty. Their home is both an assertion of the primacy of an idealized culture defining their lifestyle, and a tacit admission of their ambitious political goals for Cornell's career in Shanghai. 


\section{Columbia Road}

Shanghai architect Laszlo Hudec built a home for his family in Shanghai that not only displayed his commitment to craftsmanship, but also created an enhanced cultural and social link to Britain that was advantageous to his career.

The Tudor Revival developed in England between 1890 and $1940 .{ }^{64}$ The style was tied to the larger Arts and Crafts ethos of the 19th century. Its rise in popularity began at a time when the modern processes of industrialization and urbanization were having a marked effect on Western commercial centers like London. The industrial revolution was responsible for a great deal of anxiety amongst citizens, and Arts and Crafts was seen as an antidote to what they saw as the impersonal and untruthfulness of factory-made goods. The Arts and Crafts responded to processes of mechanization and industrialization by revaluing thoughtful, hand-made, and useful craftsmanship. It gained momentum with the writings of Augustus Pugin, John Ruskin, and William Morris, whose writings and views were disseminated in journals and at lectures.

In addition to the revival of thoughtful craftsmanship, Tudor architecture was believed to be in harmony with nature. Moreover, the organic, asymmetrical massing fit within the picturesque ideal of a simple life in the countryside. This quality made Tudor houses especially well suited to the principles of landscape design valued by the English Picturesque in the 18th century. Although carefully planned, the English Picturesque landscape sought to evoke the natural terrain with asymmetrical sightlines and rolling, pastoral compositions. The principles of the picturesque were also applied in Shanghai to

\footnotetext{
${ }^{64}$ Lee Goff and Paul Rocheleau. Tudor Style: Tudor Revival Houses in America from 1890 to the Present. (New York: Universe, 2002), 10.
} 
the private homes and gardens of the wealthy.

A romantic take upon medieval English vernacular typology, the Tudor Revival created a tangible link with the past evoking a distant English heritage. Similar to other revival styles, the Tudor privileges an idealized historical viewshed of English culture and history. ${ }^{65}$

By the 1920's the Tudor style was a popular style for suburban homes in England and in America, and was having a marked effect on domestic architecture in Shanghai. It was grasped upon my many popular monthly architectural magazines, such as the British publication The Ideal Home. [Fig. 4.1] Unlike other popular styles in Shanghai, which were adopted for many different domestic typologies, the Tudor Revival was most popular with single family detached homes. Designing in the Tudor style was one of the most popular choices for domestic architecture in Shanghai. Even today it is almost inescapable, peering at the visitor over tall walls in the French concession, and as present in the Western suburbs of the French Concession as it is in the American Concession.

\section{Columbia Road}

Ladislaus (Laszlo) Hudec was one of the most prolific architects in Shanghai. He was commissioned to build residential and commercial buildings across the city. He was an Hungarian who moved to Shanghai and practiced architecture in the interwar period. His clientele ranged from Chinese to Westerners, churches to large international firms. ${ }^{66}$ Architectural education prior to World War I shaped ambidextrous architects. They

\footnotetext{
${ }^{65}$ Andrew Ballantyne and Andrew Law. "Tudoresque Vernacular and the Self-Reliant Englishman." In Built from Below: British Architecture and the Vernacular, edited by Guillery, Peter. (New York: Routledge, 2011), 125.

${ }^{66}$ Lenore Hietkamp, Laszlo Hudec and the Park Hotel in Shanghai. (Shawnigan Lake, BC: Diamond River Book, 2012), 22-26.
} 
received a traditional Beaux Arts education in classical styles and methodology. In addition, they could also produce newer works incorporating original and contemporary styles and methods of design. Hudec was no exception, as evidenced by his drafting skill and attention to clients' stylistic preferences. ${ }^{67}$

In the mid 1920's the Municipal Council extended their territory West yet again, constructing 13 new "Extra Settlement" roads, which were quickly subsumed into the concessions. American businessman Frank Raven jumped at the opportunity presented, and his company, Asia Realty Company bought 16.5 acres of land intended for high end suburban residences. Hungarian project manager Hugo Sandor oversaw the development called Columbia Circle. ${ }^{68}$ The homes were marketed at families looking to escape the bustling city. They were located in a quiet neighborhood at the edge of the Concession, each featuring lush gardens and designed in many different styles according to the taste of the client. Of the 40 houses under development by Asia Realty for Columbia Circle in 1932, 26 were designed by Hudec. ${ }^{69}$

Columbia Circle demanded Hudec's close involvement. In 1930 he designed and completed construction of a luxurious Tudor home nestled in a rolling picturesque landscape at the edges of the French Concession for his family. The house would allow him to be close to his work at Columbia Circle, and would allow his wife and three children to enjoy the tranquility of the suburbs. [Fig. 2, 3, and 4] The house was built with materials from a number of different projects he was working on at the time, and is a thoughtfully

\footnotetext{
${ }^{67}$ Hietkamp, Hudec, 24-25.

${ }^{68}$ Hua Xiahong and Michelle Qiao. Shanghai Hudec Architecture. (Shanghai: Tongji University Press, 2012) 113. ${ }^{69}$ Ibid.
} 
designed example of the Tudor revival in Shanghai in its attention to detail and careful craftsmanship. ${ }^{70}$

The building is three stories in height, emphasized by twin elongated red brick chimneys at each side topped with decorative chimney pots. The facade features brickwork on the ground floor, and decorative half-timbering on the second and third. The rhythm of the half-timbering is continued by the tall, narrow windows with small, square window panes. The steeply pitched roof and prominent cross gables further add to the picturesque composition. The massing is asymmetrical, enhanced by subtle variation in details such as the timbering at the roofline.

Historian Leonore Heitkamp uncovered photos of the building's original interior. The rich materiality of the exterior continues to the interior; carefully crafted wood paneling and moldings which, according to Hietkamp, were carved by orphans at a Jesuit school in Shanghai for whom Hudec, a devout Catholic, was a patron. ${ }^{71}$ [Fig. 4.5] Wood floors also display a high level of craftsmanship, and photographs show that these details include herring bone parquet and dark, ribbon inlay at the corners.

The entry hall was richly outfitted in marble and hardwood, emphasising the transition from a liminal space at the entry to the intimate interior of the home. [Fig. 4.6] The visitor initially enters through a rounded arch wooden door into a small, barrel vaulted entryway with white walls and white marble floors. Just beyond this threshold, white walls and tiles give way to rich, dark wooden paneling; here there is a space to hang one's hat and jacket just below a model of a Chinese junk, one of many ships that decorate the

\footnotetext{
${ }_{70}$ Ibid., 99.

${ }^{71}$ Lenore Hietkamp, "Understanding Laszlo Hudec, Shanghai Architect." Diamond River Books, accessed 02/01, 2014, http://www.heatherfieldediting.com/Hudec/index.html.
} 
house. The wood floor and paneling of the hallway is continued at the ceiling, which is lofted and slightly higher than the entry, where large wooden beams emphasise depth and shadow of wooden panels between. This intimacy of the space draws the gaze to the rich materials and beautiful craftsmanship of the home.

The dining room [Fig. 4.7 and 4.8] also incorporates herringbone floors and wooden paneling. However, the dining room is aesthetically more airy and light in comparison to the entry hall thanks to the white, barrel vaulted ceiling. The ceiling showcases Tudor style moulded plasterwork in delicate, geometric patterns, some with arabesque tracery and floral ornamentation at the center, breaking up the stark geometries into an aesthetically pleasing and balanced composition. Another angle shows the view across the diningroom towards the window. [Fig. 4.8] Here delicate arabesque tracery at the termination of the vaulted ceiling gives way to dark paneling and drapery around the square panes of the long, rectangular window.

The house itself was originally sited at the north east corner of a large piece of property. [Fig. 4.4] The approach to the house brought visitors along a straight, carefully manicured path that terminated in a circular drive in front of the house. The remainder of the land was given over to picturesque gardens, which are shown in Hudec's original plans as well as in photographs of the house. While meticulously planned, the lush clumps of vegetation of different textures and heights connected by sweeping fertile green lawns was an attempt to bring the home in harmony with nature, a practice that reflected the Arts and Crafts interest in the natural and picturesque. Here, in an intimate family home set in a lush picturesque garden, the Hudecs would be able to lead an ideal family life. 
Hudec's architectural skill was refined yet broad in scope. In many ways Hudec was uniquely positioned to make the most of his family's new home. As evidenced by his work in Shanghai, he was as comfortable with Spanish style villas as with Art Deco skyscrapers. Well traveled and up to date on the state of contemporary architectural practice in America and Europe, one might wonder why Hudec chose to design his own home in the Tudor style. ${ }^{72}$ Or, as John Golag, a frustrated modernist and critic complained at the time, "Why do we live in a sort of half-baked pageant, always hiding in the clothes of another age? ${ }^{73}$

By building a home in the Tudor Revival style, Hudec was attempting to negotiate his own identity. In the scope of these negotiations architecture becomes a powerful tool to give physical and spatial substance to negotiations. In Shanghai Hudec's Hungarian nationality was an obstacle. As a Hungarian he was not protected under the same rights as citizens of Britain, the United States, or other Western countries who had been granted extraterritorial rights in Shanghai. ${ }^{74}$ Furthermore, there were negative social and political associations for Hungarians, whose country had been aligned with Germany in the First World War. Yet, it would be this same connection that kept Hudec and his family out of the harsh Japanese-run internment camps during the Second World War. ${ }^{75}$ In 1930, however, British dominance was the key to Hudec's success and had the benefit of bestowing upon his work the perception of legal authority and protection that he was not actually afforded.

The British exerted a powerful cultural and political sway over the foreign concessions of Shanghai that Hudec wanted to draw upon. How could Hudec, an

\footnotetext{
${ }^{72}$ Hietkamp, Hudec, 66.

${ }^{73}$ Gloag, John. Designs in Modern Life. (London: George Allen \& Unwin, 1934), 19-20.

${ }^{74}$ Hietkamp, Hudec, 22.

${ }^{75}$ Hietkamp, Hudec, 22.
} 
Hungarian, begin to associate himself with Britain?

Hudec had two strategies to connect himself to Britain. First, Hudec relied upon his wife, Gisela's distant yet elite British relations to give his association weight. In fact, it was Gisela and her British family's ties to Shanghai contacts that allowed the Hudecs to engage in the privileged and vibrant social life prized by Shanghailanders ${ }^{76}$ Networking was as important for architects in Shanghai as it is for them today, and many of Hudec's commissions were won thanks to connections he made in Shanghai society.

Gisela's concrete familial ties to British aristocracy legitimized Hudec's second strategy: to design a home in the British Tudor style thereby creating a tangible and recognizable link that would reaffirm this cultural identity. During the 1920's and 1930's Tudor homes were no longer built with the artistic quality and craftsmanship of 19th century iteration. In fact, in both American and England the Tudor style had become a mass produced typology, ubiquitous in new suburban developments. ${ }^{77}$

This would have been no surprise to Hudec, who traveled several times to America and to Europe in the late 1920's and in 1930, where he studied contemporary trends in architecture, new developments in design and construction, always sketching and studying what he saw as material for his work in Shanghai. ${ }^{78}$ His sketches and diaries demonstrate that he was fascinated by the modern movement in America, studying the New York skyscraper, cinemas, and other modern architectural developments. In fact, between 1928 and 1934 Hudec completed sixteen building projects in modern styles, and several more

\footnotetext{
${ }^{76}$ Hietkamp, Hudec, 22.

${ }^{77}$ Ballantyne and Law. "Tudoresque Vernacular," 141.

${ }^{78}$ Hietkamp, Hudec, 66.
} 
that used modern materials and technologies. ${ }^{79}$ However, for his own home Hudec did not choose a modern style.

Although mass-produced Tudor homes were criticized for a loss of integrity, many valued their capacity to empower their occupants, lending a sense of morality and depth of character and indicating social advancement of the occupant. ${ }^{80}$ Moreover, the style was favored by those who wanted at once to appear modest yet live in a home with a tangible connection to an English heritage. Tudor homes evoked a sentimental view of British culture and heritage. In 1920, Ideal Home published an illustration entitled "A Small Country House" shows a large, two story Tudor home set at the rear of a simple, hedge-lined garden. The description read, 'the desire has been to secure a suggestion of homeliness and comfort, something free from all pretension and ostentation; something, indeed, traditionally English'. ${ }^{81}$

Hudec's home at 57 Columbia Road is an example of a thoughtfully crafted Tudor revival house. In addition to designing a comfortable home for his family, building a Tudor home was a strategy of negotiation. Hudec hoped that the new home would have a positive influence on his social position in Shanghai, achieved through associating himself with Britain. This cultural association would enhance his perceived political and legal standing, and perhaps even win him additional commissions.

\footnotetext{
${ }^{79}$ Hietkamp, Hudec, 66.

${ }^{80}$ Ballantyne and Law, "Tudoresque Vernacular," 141.

${ }^{81}$ Ideal Home, April 1920, 133.
} 


\section{The D.V. Woo House}

The D.V. Woo House provides a case study in which to re-examine Shanghai architect Laszlo Hudec at a later point in his career and to look at the home he designed for a wealthy Chinese client. The construction of a modern four storey villa in the heart of the International Settlement presented an opportunity for both Hudec and his client, D.V. Woo, to cloak themselves in a cosmopolitan sensibility. The result was a home that represented intercultural values marrying tradition to modernity.

Streamline Moderne was a style that celebrated the moment, embodying the openness, cosmopolitanism, and rapid growth Shanghai experienced in the 1930's. To some, revival styles tied to tradition and heritage were no longer relevant to the modern, vibrant, and eclectic culture of Shanghai. The time was ripe for a new, fresh style responding to modern Shanghai, without remaining indebted to a cumbersome history. In contrast to revival styles that are rooted in the past, asserting and reasserting ideal heritage and the dominance of a culture far away, Streamline Moderne was a style that Shanghai could develop in its own right.

Outside of the sphere of industrial design, architectural historians have paid little attention to Streamline Moderne. Typically, it is positioned as a streamlined branch of Art Deco. At times it leans heavily on Art Deco, adapting motifs, massing, and rhythms in different iterations. Some theorists link this style to the development of aeronautical technology that allowed for high speed and little drag resulting in streamlined, smooth exteriors. In architecture Streamline Modern borrows and simplifies the long, curvaceous 
masses of the early Art Deco and further reduces and elongates the horizontal lines. Exterior walls are typically smooth, corners and windows are often rounded, and the roofline is flattened. Common attributes include porthole windows, chrome detailing, and long, curving railings. The overall massing often emphasizes the horizontal, and forgoes the regularity and symmetry seen in Art Deco in favor of irregular, asymmetrical massing. Exterior decoration is minimized and sometimes eschewed altogether.

Although it may reference Art Deco, Streamline Moderne is considered a modern style and, in its heyday, was associated with the new and cosmopolitan, and even the promise of a bright future. Rather than repeating the staid and expected architectural styles of Europeans' ancestral pasts, it was a style that could grow and expand in Shanghai without tacitly claiming allegiance to a country far away.

The rise of Art Deco and Streamline Moderne mirrored Shanghai's dramatic rise in power, prosperity, and influence during the 1920s and 1930s. This coincidence, combined with an atmosphere of openness and eclecticism already found in Shanghai, meant that new architectural styles were easily adopted. It was embraced by Shanghai modernists regardless of their cultural or ethnic background. It is seen in a variety of different buildings, from the villas of wealthy Chinese, to the apartments of foreign diplomats, to movie theaters and hotels. Shanghai's Streamline Moderne buildings were influenced by contemporary iterations in America and France, and were also responsive to Chinese forms, making Shanghai examples unique within the typology.

The D.V. Woo House was designed by Laszlo Hudec, the architect who designed 
and owned the Tudor style house at 57 Columbia Circle. [Fig. 5.1] It was designed for D.V. Woo (sometimes known as Wu Tongwen 吴同文 or D.V. Wood), a rich Chinese businessman and uncle of Chinese American architect I.M. Pei. ${ }^{82}$ The building, located on Hardoon Road (now Tongren Road) in a busy neighborhood of the International Concession, was completed in 1938 and, thanks to the use of glazed jade-green tiles covering the building's exterior, it was known locally as "The Green House. ${ }^{183}$ Woo was a businessman with the foresight for choosing the right investment at the right time. As it became clear that war was eminent, Woo invested in green dye, which he was then able to sell for a large profit during the war. This simple yet profitable insight helped Woo fund a streamline moderne villa commissioned from Hudec. ${ }^{84}$

The construction of the modern four storey villa presented an opportunity for both Hudec and Woo to align themselves within a modern, international sensibility. He hoped that this building would evoke a modern view appropriate to Shanghai, distinguishing itself from other local houses, including his own at 57 Columbia Circle, which modeled European and American historical styles. ${ }^{85}$ In his design Hudec was able to experiment with new technologies as part of a search for a modern architectural language. Purportedly, Hudec assured $\mathrm{Wu}$ Tongwen that it would remain the most modern house in Shanghai for years to come. $^{86}$

\footnotetext{
82 "Fragments of Shanghai; Old Shanghai Architecture." The Flying Room, accessed 11/2, 2013, http://www.theflyingroom.com/blogs/news/7515666-fragments-of-shanghai-old-shanghai-architecture.

${ }^{83}$ Hua Xiahong and Michelle Qiao. Shanghai Hudec Architecture. (Shanghai: Tongji University Press, 2012) 87.

${ }^{84}$ Johnston, Art Deco Shanghai, 202.

${ }^{85}$ Hietkamp, Hudec, 25.

86 "When Europe Met Asia..." ArchDaily.
} 
The use of a modern style sets this villa apart, borrowing the stylized elegance of more sumptuous villas and careful to produce a harmonious whole. The house incorporates long, horizontal balconies that wrap around the house with a processional, curving, stairwell leading from the second floor down to the garden. At the front corner, a modern cylindrical turret housing a sunroom encased in glass dominates the view, and draws the eye up the full four floors of the building. The north facade incorporates long, horizontal plate glass windows into a streamline facade. Minimal Streamline Modern detailing, such as geometric ornamentation in the ironwork of the windows looking into stairwell, and the elegant streamline curve of the banister is contrasted with large solid masses of wall, which create a composition that exhibits visual restraint and taste without sacrificing style. [Fig.

\section{$5.2,5.3$, and 5.4$]$}

Hudec and the D.V. Woo house have recently been the subject of museum exhibitions in both Shanghai and Hungary. Although a lack of photographs and other documentary evidence limits discussion of the interior design the interior still retains many of the original features. According to Arch Daily's review of a 2013 retrospective of Hudec's work in Shanghai, the Woo House was famous for its staggering array of rooms (no surprise in a house that measures close to 18,500 square feet). The house made use of modern conveniences, for example, it was the first home in Shanghai with air conditioning and an elevator. Modern conveniences were paired with a lavish interior. The house was designed with an Italian marble staircase, and fashionable copper handrails and radiators. ${ }^{87}$ One of the new technologies Hudec used in the Woo house and some of 
his other commissions was durametal, a nickel-silver material that allowed Hudec to incorporate curving shapes into the railings, doors, and security grills ${ }^{88}$ Throughout the house geometry is the basis for all decoration; patterns of curves and right angles manifest as much in the massing of the building as in its decorative motifs.

The house was designed to meet the needs of a contemporary Chinese family, and can be read as a manifestation of the modern, eclectic sensibility of cosmopolitan Shanghai. Plans of the first and second floors evidence a physical separation between the traditional and the modern. [Fig. 5.5 - 5.8] The ground floor is divided by a carport that brings the family directly into the entryway. Here, the family could exit to either the northern or southern wings of the building, which connected at the second floor. The northern wing reflected traditional Chinese domestic spaces. It housed a vestibule, a Chinese style reception room, an ancestral hall, and a Chinese kitchen. Meanwhile, the southern wing was meant for modern entertainment and relaxation, and had a billiards room larger than the ancestral hall, as well as a sizable Western style parlor. The spacious second floor, reached by either the elevator or Italian marble staircase, featured more room for entertaining. A second western kitchen, pantry and other domestic rooms are hidden from view at the back of the house. Meanwhile, a modern south facing dining room [Fig. 5.9], living room, and sunroom, used by the Woo family and their guests, featured an open plan that dissolved boundaries between the interior living spaces and the terrace and garden. Large floor to ceiling windows and doors opened to a wide terrace, eliminating the barriers between the interior and exterior. The terrace became another important room of the

\footnotetext{
${ }^{88}$ Lenore Hietkamp, Laszlo Hudec and the Park Hotel in Shanghai. (Shawnigan Lake, BC: Diamond River Book, 2012), 76.
} 
house, which flowed into the garden by way of a gently cascading staircase that hugged the curve of the exterior of the billiards room.

With the design of the D.V. Woo house Hudec experimented with a new, contemporary architectural style. The dramatic flair of the building expresses the vigor and excitement of Shanghai society in the 1930's. Its elegant curvaceous exterior was an attention grabbing advertisement of D.V. Woo's success, and high, solid garden walls, a barrier between the public streets and the family home emphasised the exclusion and superiority that was the privilege of the elite in Shanghai.

While the Streamline Moderne may have seemed a strictly modern choice, the configuration of the interior spaces harmonizes traditional Chinese cultural practices with modern activities and ways of living. Hudec was known for his ability to respond to his client's needs, and the Woo family commissioned a home that could accommodate intercultural practices. The hybrid configuration of the rooms leads to a successful modern and cosmopolitan ethos. The Woo family led a life that was neither a slave to tradition nor dictated by modernity. Instead, they lead a life that was a hybrid of the two, the domestic spaces responding to the traditional and the modern. The Confucian practice of ancestor worship would be maintained and traditional spaces ensured family members could be received with the proper accord, and traditional meals could be prepared in the Chinese kitchen. Family and social connections could be entertained in the billiards room, the sprung dance floor encouraged longer nights of dancing, and central air conditioning protected against the hot and humid Shanghai summer heat. All who entered the sleek streamline of Hudec's D.V. Woo House could be sure they were in a modern house 
belonging to a modern family . 


\section{Conclusion}

This thesis discusses the role of domestic architecture in negotiations of culture, class, and identity in Shanghai between 1920 and 1940. Negotiations are a constantly present and fluid attribute of architectural styles. Shanghai was a site of confluence for many cultures, which experienced rapid population growth through the 1920's and 1930's. Homes built in Shanghai during these years provided the architect and patron an opportunity for negotiation, and the houses the designed became the language they used to signal their identity, culture, and class.

In this thesis the term negotiation describes the purposeful exchanges between Shanghai residents, intended to achieve shared understanding, or mutually-understood expression of self. In order for exchanges to be successful, individuals chose specific and clear means by which to express themselves. One of the places these negotiations took place was in the domestic sphere, where architectural language was employed to negotiate identity, culture, and class. Strategies of negotiation in architecture include the use of familiar markers of power, solidity, strength, and beauty in order to achieve shared understanding.

After giving an historical background, the second chapter discusses domestic spaces, identity, and cultural production through the work of critical theorists. Theoretical positions discussing culture, myth and narrative, and domesticity set the stage for subsequent case studies. This framework allows us to consider Shanghai as a text and cultural monument, and to discuss Shanghai's symbolic representation in terms of negotiations of identity, culture, and class. 
Finally, theoretical positions can be supported by case studies from the Shanghai domestic sphere. Each case study was chosen carefully, with the intention that they respond and build upon one another. The case studies are culled from the still-extant homes and mansions of Wealthy Shanghailanders constructed between 1920 and 1940. Additionally, each case study was chosen because there is evidence to support sustained analysis of the negotiations that surround it. Information about the architecture, the state of the field at the time, the configuration and materiality of the building are important to this question. Just as important is the consideration of the client's personal life and background. Biographical details such as profession, social standing, nationality, and family tree color the client's motivations and can help elucidate details about the stylistic choices made. Also of interest is information about the architect and others involved in the design process. Each case study draws as much upon the home as the family who lived in it to illustrate the role of the architecture in negotiation.

This thesis focuses upon the homes of the wealthy elite in Shanghai due to the fragmentary nature of extant sources relating to Shanghai's domestic architecture in the concessions, and the people who lived there. The view presented of the domestic sphere is necessarily incomplete, and the conclusions drawn may not apply equally to all classes of the Shanghai population. Left unexplored is the extent to which less wealthy citizens were able to negotiate their identity in Shanghai. Further research is necessary to understand how negotiations of identity for these groups can add to our understanding of the historical changes associated with concession-era Shanghai. Moving forward, the work of Neo-Sensationalist writers provides an interesting point of departure for considering 
non-elite histories. These writers, who often rented rooms and survived on small salaries, drew upon their own lives for literary material. In these accounts the domestic sphere is replaced by an enamored view of public and recreational spaces; of boulevards, public transport, cafés, and cinemas.

This research adds to current literature, and has the potential for further development. This thesis focuses on only a few examples from a wide field of domestic architecture. Many architectural typologies were excluded, such as the local lilong typology, which have only been considered in a few histories. Scholarship presently does not address the rich variation of styles, the development of neighborhoods, or the even the state of architectural practice in Shanghai between 1842-1950. The terrain is virtually unmapped. While there are a limited number of publications available in Chinese, especially from Tongji University, these have not yet been translated into English and many are no longer in print. Likewise, much of the research completed and published by French scholars is unavailable except in French. A knowledge of English, French, and Chinese is critical to incorporate and synthesize not only the work of current scholars, but also move forward with research. Few historians possess the range of linguistic skills required to make use of all archival materials.

In 2015 Shanghai will host the International Coalition of Art Deco Societies. The attention that the conference will bring will most certainly result in a renewed interest in the vibrant array of Art Deco and Streamline Moderne buildings and homes that dot Shanghai. As more and more of Shanghai's historic urban fabric gives way to developers, the attention of preservationists and scholars becomes more relevant. China's still-young 
historic preservation movement needs strong advocates who are able to sway the hearts and heads of investors and developers. Projects like Xintiandi (New Heaven and Earth) which restored and reused a neighborhood of historic lane houses for an upscale outdoor shopping plaza are a step in the right direction. While their preservation strategies might be questionable, there is no doubt that projects like Xintiandi demonstrate that Shanghai's historic urban fabric can be as appealing as the most modern highrise.

The preservation movement also faces the very real challenges presented by the current condition of historic buildings. When the Communist Party came to power, many homes and apartments were divided up into single room apartments and given to families who moved in from the countryside. Today, many apartments meant to house a small family of three are home to many families. These families are frequently multi generational, all eating, sleeping, cooking, and playing in one room. These homes are dangerous to the occupants' health, are structurally unsound, improperly ventilated, and pose major fire risks. By and large these homes do not have running water, and many still use chamber pots.

Preservationists from the West, eager to see a beautiful building restored as they are back home, are not sensitive to the realities of life in these tiny one-room apartments. While they daydream about fixing up a former Mediterranean style garden apartment and and planting flowers, the current tenants dream of demolition. When old properties in Shanghai are bought by developers tenants are offered a golden ticket out of a one room existence to a new, habitable, apartment in the suburbs and given a substantial amount of money. 
Before fighting to preserve buildings, the preservation movement must consider the lives of the current tenants. A solution needs to be reached that preserves the building, and improves the lives of the people currently living there. There is no easy answer, but I believe that the first step is convincing the Communist Party that historic preservation is meaningful and worthwhile. Without the support of the CCP, the fight to preserve Shanghai's historic urban fabric is futile. 


\section{Bibliography}

"China: Cultivated Lands." Time 35, no. 11 (3/11, 1940).

"Fragments of Shanghai; Old Shanghai Architecture." The Flying Room, accessed 11/2, 2013, http://www.theflyingroom.com/blogs/news/7515666-fragments-of-shanghai-old-shanghai-ar chitecture.

"Texts \& Data; Buildings." Virtual Shanghai, accessed 11/15, 2013, http://www.virtualshanghai.net/Data/Buildings.

"When Europe Met Asia... with Delicious Results." ArchDaily, accessed 2013, 10/30, http://www.archdaily.com/tag/laszlo-hudec/.

Ashcroft, Bill, Gareth Griffiths, and Helen Tiffin. The Post-Colonial Studies Reader. London ;New York: Routledge, 1995.

Ball, Emma R. and Mount Vernon Ladies' Association of the Union. Washington's Home and the Story of the Mount Vernon Ladies' Association of the Union. Richmond: Whittet \& Shepperson, printers, 1912.

Ballantyne, Andrew and Andrew Law. "Tudoresque Vernacular and the Self-Reliant Englishman." In Built from Below: British Architecture and the Vernacular, edited by Guillery, Peter. New York: Routledge, 2011.

Bayer, Patricia. Art Deco Source Book. Oxford: Phaidon, 1988.

Benjamin, Walter and Hannah Arendt. Illuminations [llluminationen. English]. New York: Schocken Books, 1986; 1968.

Bergère, Marie-Claire. Shanghai; China's Gateway to Modernity. Stanford: Stanford University Press, 2009.

Blotner, Joseph. Faulkner: A Biography. One-volume , 1 ed. New York: Random House, 1984.

Blotner, Joseph, Albert Erskine, and Random House. Faulkner 1982; 1984.

Brandt, Lydia Mattice. "Re-Living Mount Vernon: Replicas and Memories of America's most Famous House." PhD, University of Virginia, 2011.

Burger, Eric. "Electric Treehouse; Progress and the Yangtze River." , accessed 04/20, 2013, http://electrictreehouse.com/progress-and-the-yangtze-riverl.

Cranley, Patrick, Sue Anne Tay, Tess Johnston, Lisa Movius, Bill Savadove, and Duncan Hewitt, eds. Shanghailanders and Shanghainese: Where they Lived, Worked, and Played; Still More Shanghai Walks. Shanghai Walks. Vol. 1. Hong Kong and Shanghai: Old China Hand Press, 2011.

de Lemme, Arie van. A Guide to Art Deco Style. London: Grange, 1998; 1986.

Denison, Edward and Guang Yu Ren. Building Shanghai : The Story of China's Gateway. Chichester, England ;Hoboken, NJ: Wiley-Academy, 2006.

Dikötter, Frank. The Age of Openness : China before Mao. Berkeley: University of California Press, 2008.

Fairbank, John King and Merle Goldman. China : A New History. 2 enl ed. Cambridge, Mass.: Belknap Press of Harvard University Press, 2006. 
Gloag, John. Designs in Modern Life. London: George Allen \& Unwin, 1934.

Glover, William J. "A Feeling of Absence from Old England; the Colonial Bungalow." Home Cultures 1, no. 1 (2004): 61.

Goff, Lee and Paul Rocheleau. Tudor Style : Tudor Revival Houses in America from 1890 to the Present. New York: Universe, 2002.

Green, Barbara, Tess Johnston, Ruth Lear, Carolyn Robertson, and Jos Snoodijk, eds. Patterns of the Past; Six More Shanghai Walks. Shanghai Walks. Vol. 1. Hong Kong and Shanghai: Old China Hand Press, 2008.

Grier, Katherine C. and Margaret Woodbury Strong Museum. Culture \& Comfort : People, Parlors, and Upholstery, 1850-1930. Rochester, N.Y.: Strong Museum ;Amherst, Mass., 1988.

Hamadeh, Shirine. "Ottoman Expressions of Early Modernity and the "Ineviable" Question of Westernization." Journal of the Society of Architectural Historians 63, no. 1 (2004): 32.

Hay, Jonathan. "Towards a Theory of the Intercultural." RES: Anthropology and Aesthetics no. 35, Intercultural China (Spring, 1999): 5-9. http://www.jstor.org/stable/20167015.

Henriot, Christian, Zu'an Zheng, Olivier Barge, and Sébastien Caquard. Atlas De Shanghai : Espaces Et Représentations De 1849 à Nos Jours. Paris: CNRS Editions, 1999.

Hietkamp, Lenore. Laszlo Hudec and the Park Hotel in Shanghai. Shawnigan Lake, BC: Diamond River Book, 2012.

_. "Understanding Laszlo Hudec, Shanghai Architect." Diamond River Books, accessed 02/01, 2014, http://www.heatherfieldediting.com/Hudec/index.html.

Hillier, Bevis and Stephen Escritt. Art Deco Style. London: Phaidon, 1997.

Shanghai, Revolution and Development in an Asian Metropolis. Directed by Howe, Christopher and University of London. Cambridge Eng. ;New York: Cambridge University Press, 1981.

Jesus, Carlos Augusto Montalto. Historic Shanghai. Shanghai: The Shanghai Mercury, Limited, 1909.

Johnston, Tess and Dongqiang Er. Frenchtown Shanghai : Western Architecture in Shanghai's Old French Concession. 1st ed. Hong Kong: Old China Hand Press, 2000.

—. A Last Look: Western Architecture in Old Shanghai. 4th ed. Hong Kong: Old China Hand Press, 1998.

—. Art Deco Shanghai. Hong Kong: Old China Hand Press, 2006.

Lee, Leo Ou-fan. "Shanghai Modern: Reflections on Urban Culture in China in the 1930's." In Alternative Modernities, edited by Gaonkar, Dilip Parameshwar. Durham, NC: Duke University Press, 2001.

-Shanghai Modern : The Flowering of a New Urban Culture in China, 1930-1945. Cambridge, Mass.: Harvard University Press, 1999.

Lévi-Strauss, Claude. The Way of the Masks [Voie des masques. English. 1982]. Seattle: University of Washington Press, 1982.

Liang, Samuel Y. Mapping Modernity in Shanghai : Space, Gender, and Visual Culture in the Sojourners' City, 1853-98. Asia's Transformations. London ;New York: Routledge, 2010. 
- "Where the Courtyard Meets the Street: Spatial Culture of the Li Neighborhoods, Shanghai, 1870-1900." Journal of the Society of Architectural Historians 67, no. 4 (December, 2008, 2008): 482-503.

Lopez, Donald S. Religions of China in Practice. Princeton Readings in Religions. Princeton, N.J.: Princeton University Press, 1996.

Lu, Hanchao. "Away from Nanking Road: Small Stores and Neighborhood Life in Modern Shanghai." The Journal for Asiatic Studies 54, no. 1 (1995): 93.

- Beyond the Neon Lights : Everyday Shanghai in the Early Twentieth Century. Berkeley, Calif.: University of California Press, 1999.

McLeod, Stephen A., Carol Borchert Cadou, and Mount Vernon Ladies' Association of the Union. The Mount Vernon Ladies' Association : 150 Years of Restoring George Washington's Home. 1st ed. Mount Vernon, Va.: Mount Vernon Ladies' Association, 2010.

Meng, Yue. Shanghai and the Edges of Empires. Minneapolis: University of Minnesota Press, 2006.

Pan, Lynn. Shanghai Style : Art and Design between the Wars. San Francisco: Long River Press, 2008.

Ruan, Xing. "Accidental Affinities: American Beaux Arts Architecture in Twentieth Century Chinese Education and Architectural Practice." Journal of the Society of Architectural Historians 61, no. 1 (2002).

Sears, Roebuck \&. Co. Homes of Today Sears, Roebuck \& Co, 1932.

Sergeant, Harriet. Shanghai : Collision Point of Cultures, 1918-1939. 1 American ed. New York: Crown, 1990.

Tata, Sam. "Old Pictures of Shanghai." China Today, accessed 12/03, 2013, http://www.chinatoday.com/history/shanghai.old.pictures.2.htm.

Twitchett, Denis Crispin and John King Fairbank. The Cambridge History of China. Cambridge Eng. ;New York: Cambridge University Press, 1978.

Wilson, Richard Guy, Shaun Eyring, and Kenny Marotta. Re-Creating the American Past : Essays on the Colonial Revival. Charlottesville ;London: University of Virginia Press, 2006.

Xiahong, Hua and Michelle Qiao. Shanghai Hudec Architecture. Shanghai: Tongji University Press, 2012.

Ye, Xiaoqing. The Dianshizhai Pictorial : Shanghai Urban Life, 1884-1898. Michigan Monographs in Chinese Studies. Vol. 98. Ann Arbor: Center for Chinese Studies, the University of Michigan, 2003.

Zhang, Xudong. "Shanghai Image: Critical Iconography, Minor Literature, and the Un-Making of a Modern Chinese Mythology." New Literary History 33, no. 1 (2002): 137.

Zhang, Yingjin. Cinema and Urban Culture in Shanghai, 1922-1943. Stanford, Calif.: Stanford University Press, 1999. 


\section{Illustrations}

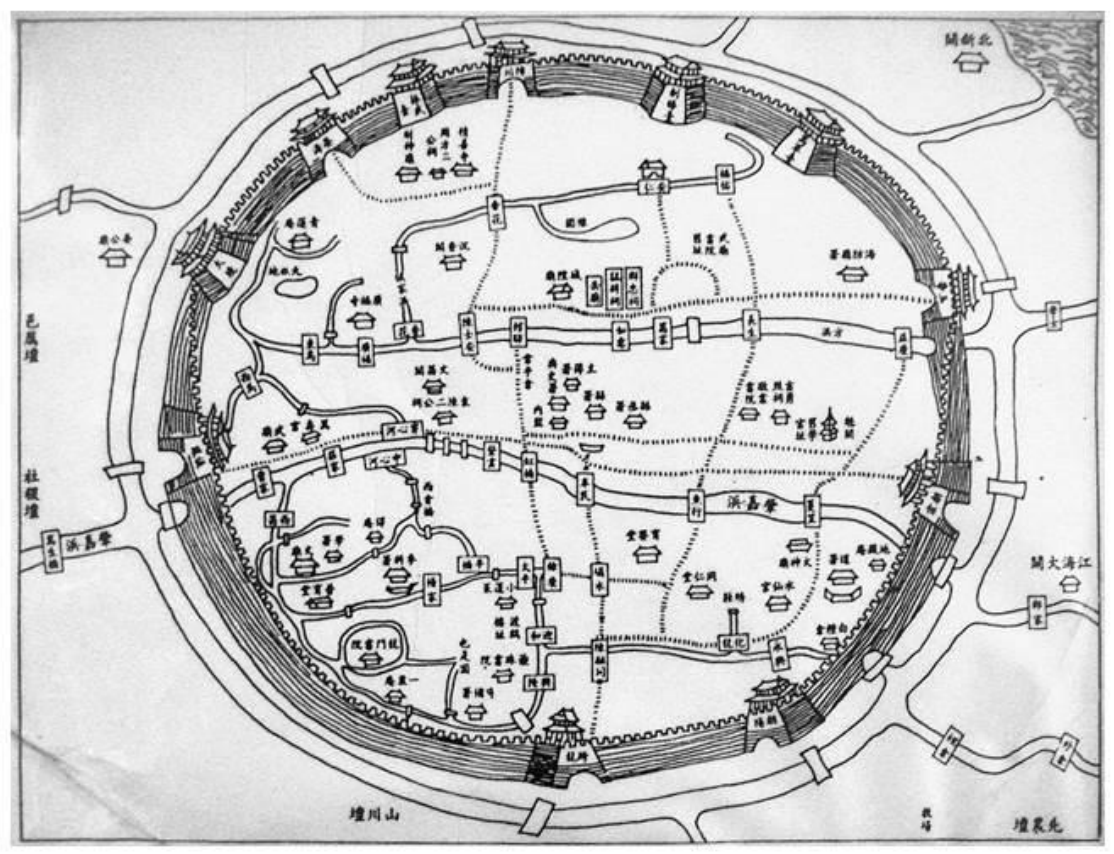

Fig. 1.1 Map of the Walled Chinese City of Shanghai, 1873. From: Shanghai Gazetteer 上海县志 (1873). 


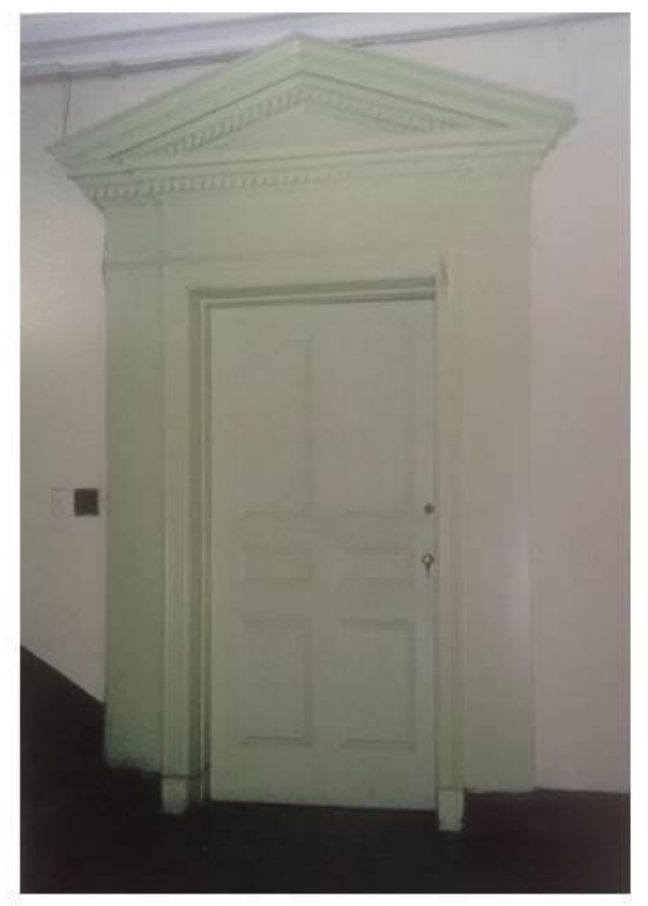

Fig. 3.6 The Franklin House, interior.

From: Tess Johnston and Dongqiang Erh, Frenchtown Shanghai: Western Architecture in Shanghai's Old French Concession. 1st ed. Hong Kong: Old China Hand Press, 2000.

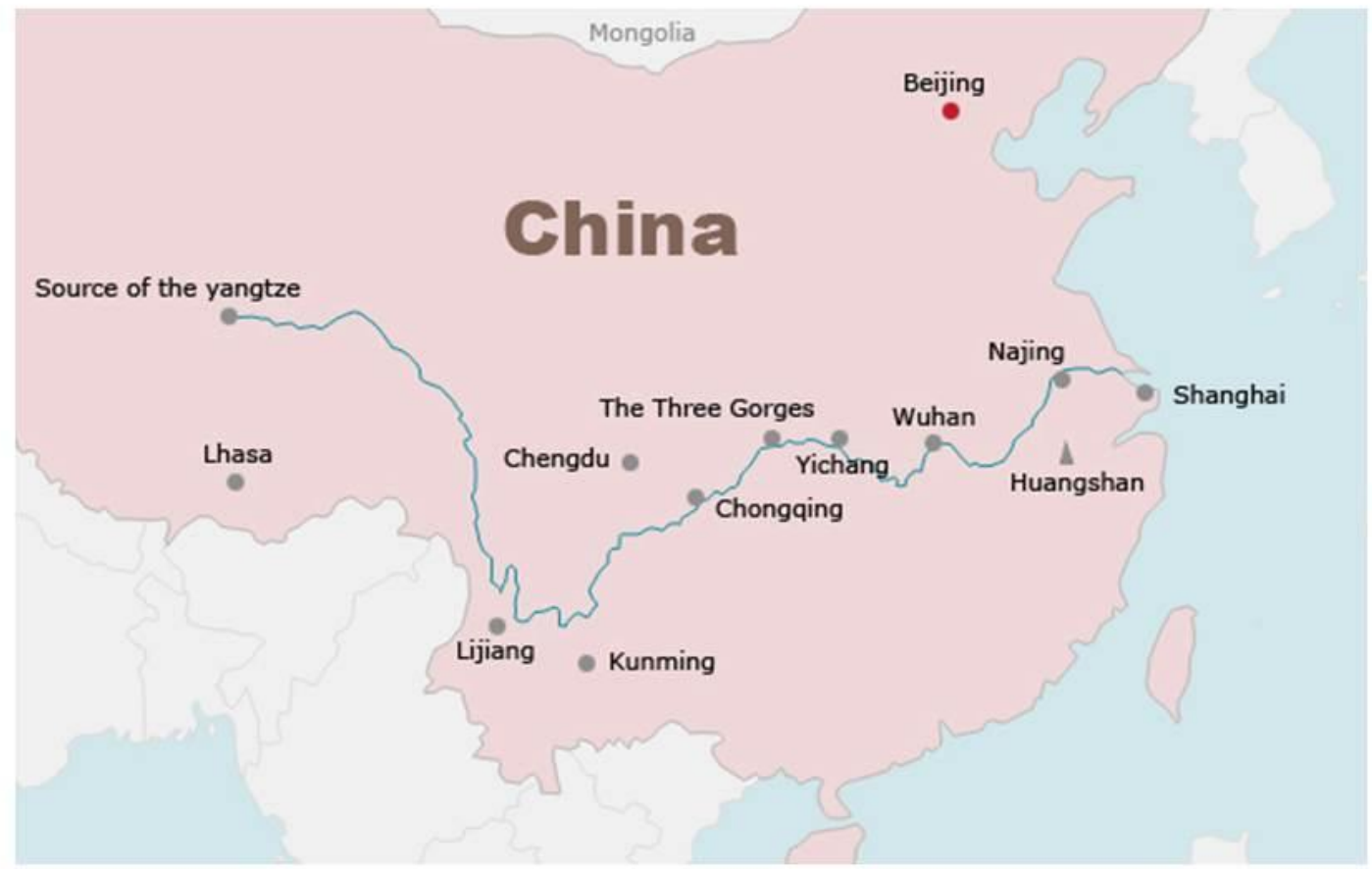

Fig. 1.2 The Yangtze River, China

From: Eric Burger, The Yangtze River, 2013. From: Electric Treehouse http://electrictreehouse.com/progress-and-the-yangtze-river/, (accessed April 20th, 2013). 


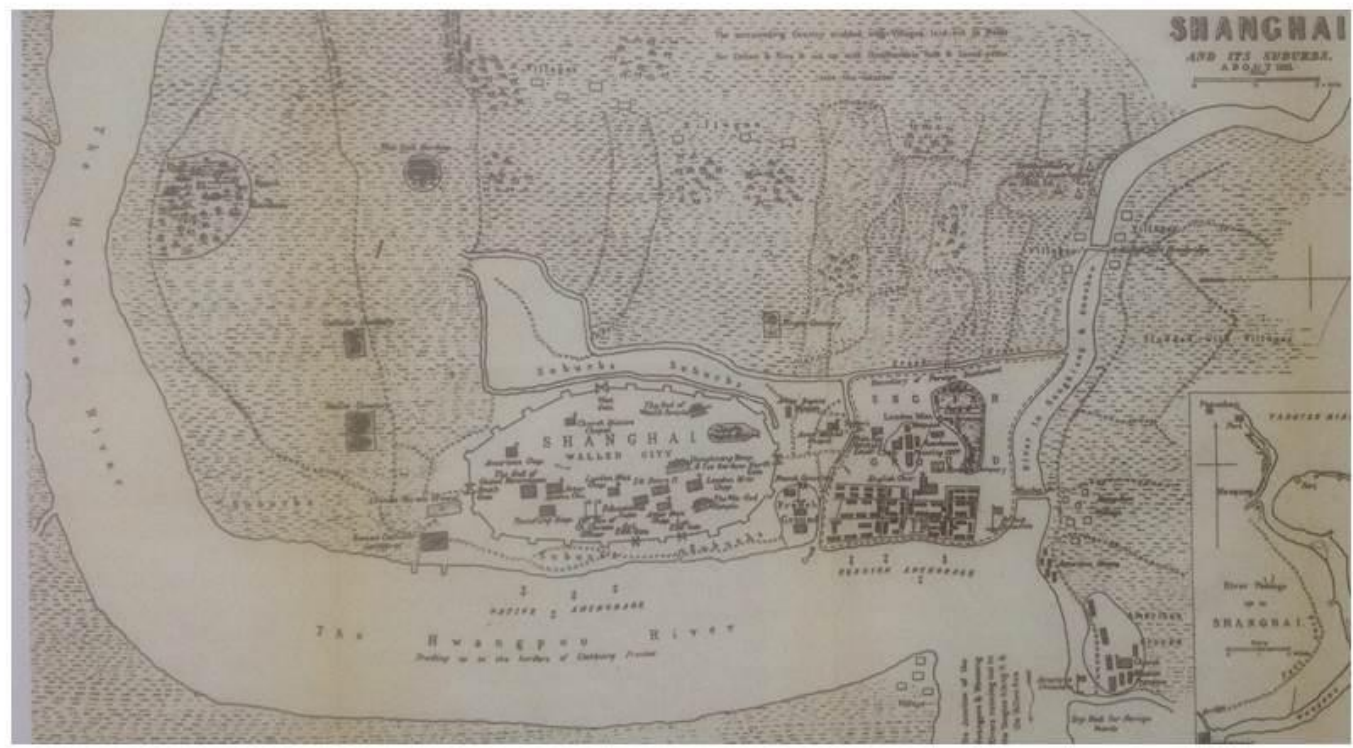

Figure 1.3 Map Showing the American, British, French concessions and the walled Chinese City circa 1875. (Note: Oriented East to West)

From: Edward Denison and Guang Yu Ren. Building Shanghai: The Story of

China's Gateway. Chichester, England; Hoboken, NJ: Wiley-Academy, 2006. 


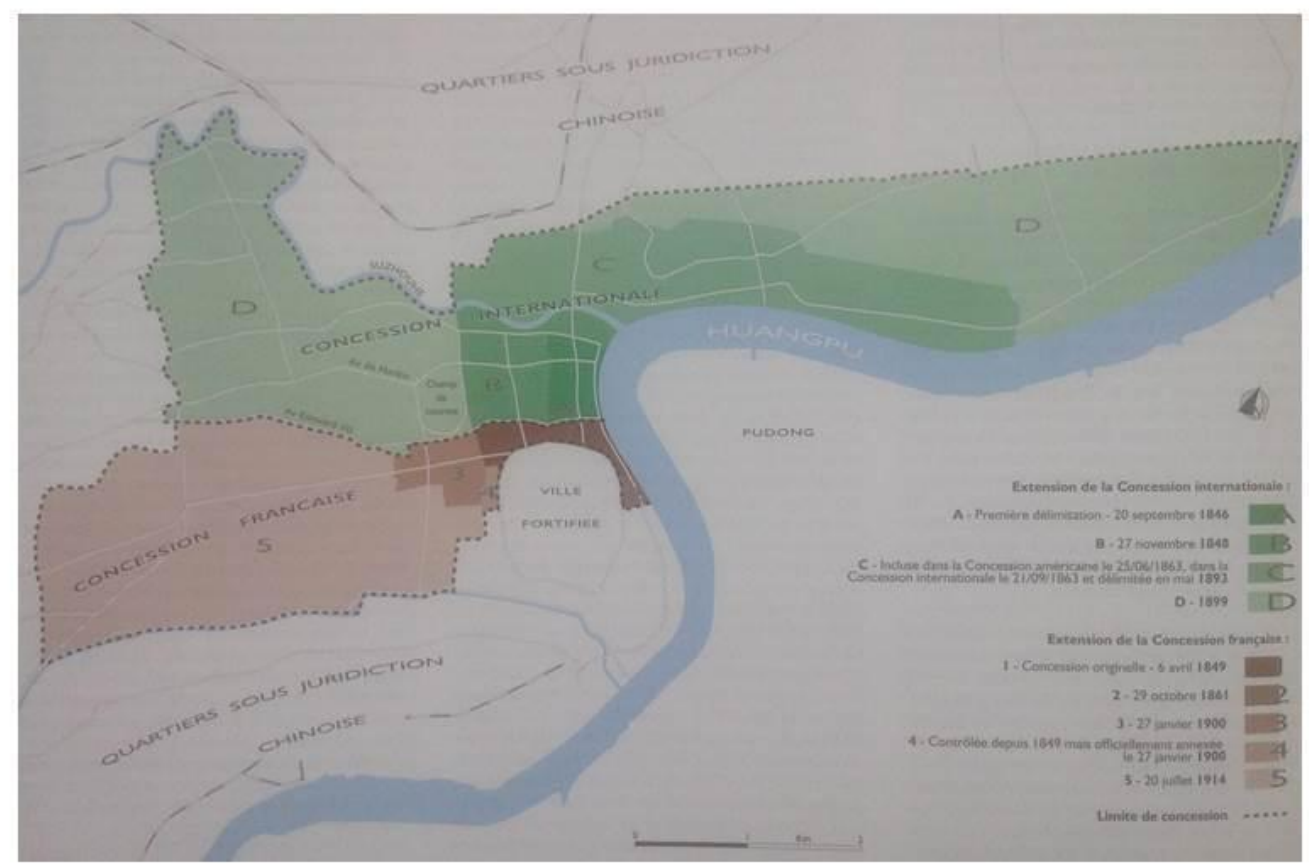

Fig. 1.4 Plan showing expansion of the Foreign Concessions in Shanghai.

From: Christian Henriot, Zu'an Zheng, Olivier Barge, and Sébastien Caquard, Atlas De Shanghai: Espaces Et Représentations De 1849 à Nos Jours. (Paris: CNRS Editions, 1999) 29. 


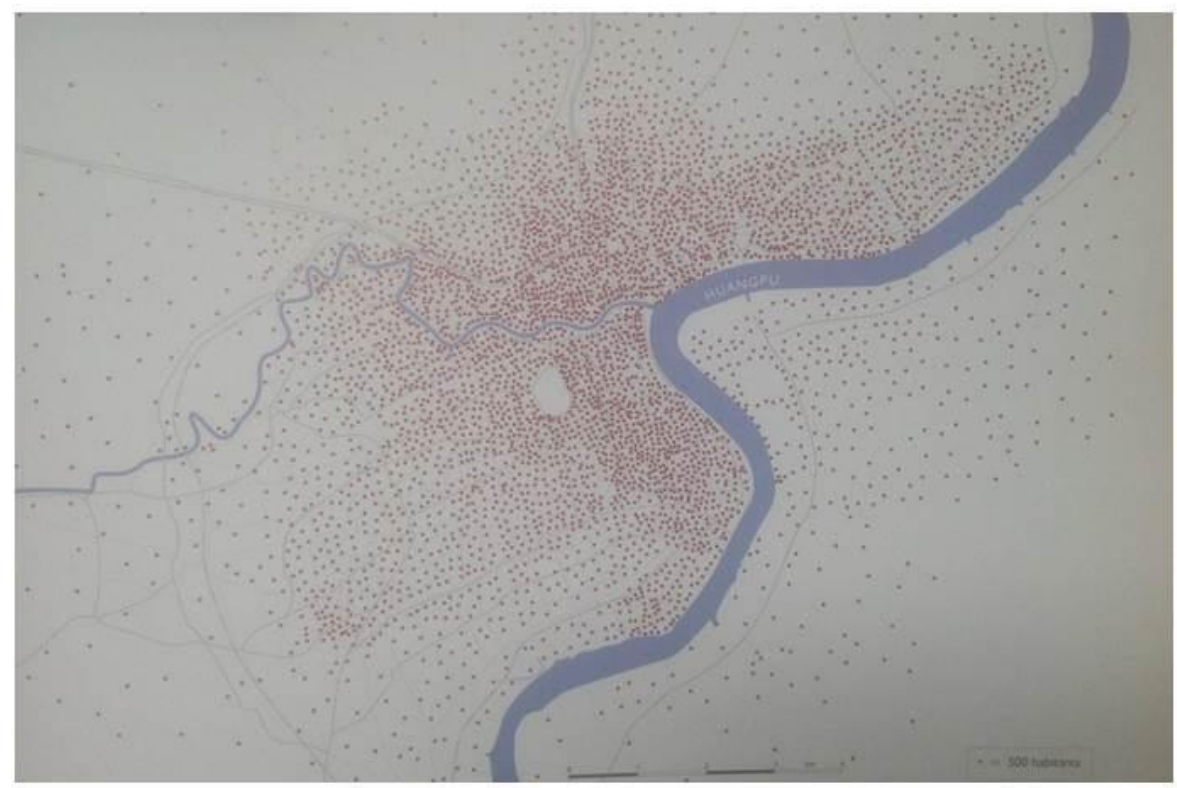

Fig. 1.5 Shanghai's population distribution in 1929, per 500 people. From: Christian Henriot, Zu'an Zheng, Olivier Barge, and Sébastien Caquard. Atlas De Shanghai : Espaces Et Représentations De 1849 à Nos Jours. (Paris: CNRS Editions, 1999) 99. 


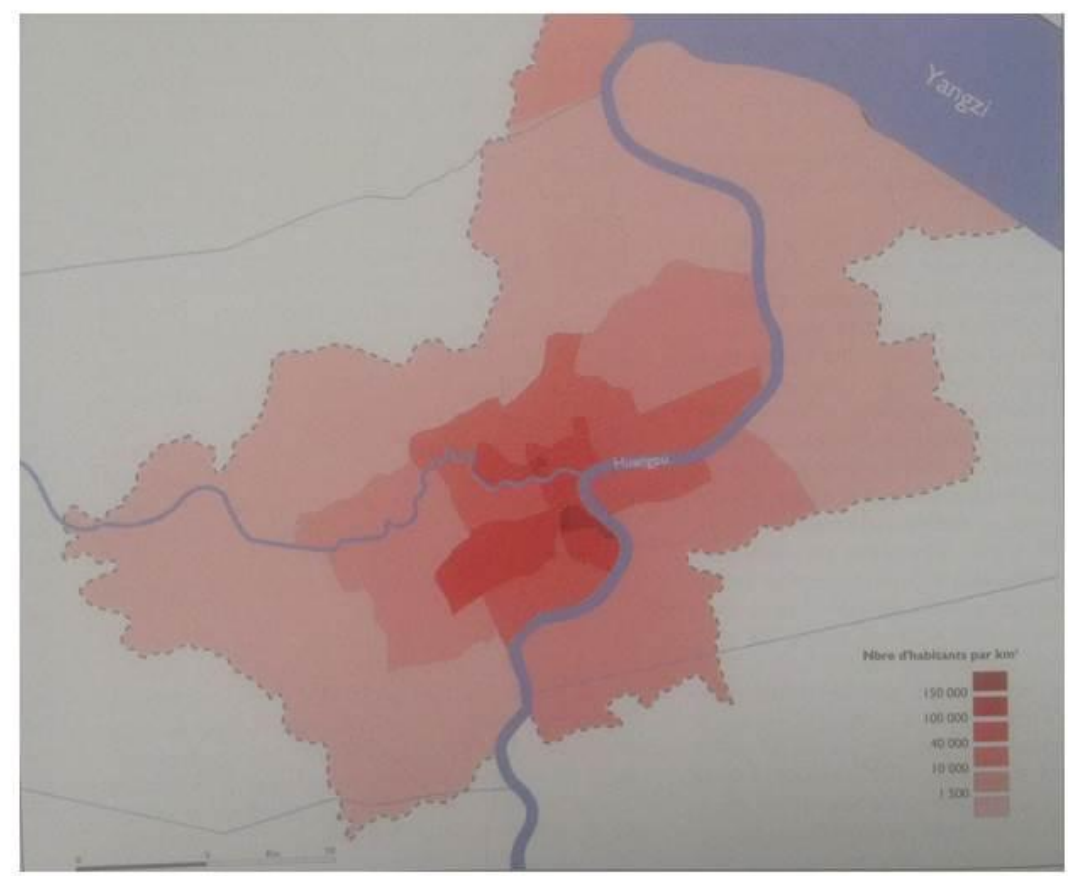

Fig. 1.6 Shanghai's population density per kilometer in 1929. From: Christian Henriot, Zu'an Zheng, Olivier Barge, and Sébastien Caquard, Atlas De Shanghai: Espaces Et Représentations De 1849 à Nos Jours. (Paris: CNRS Editions, 1999) 98. 


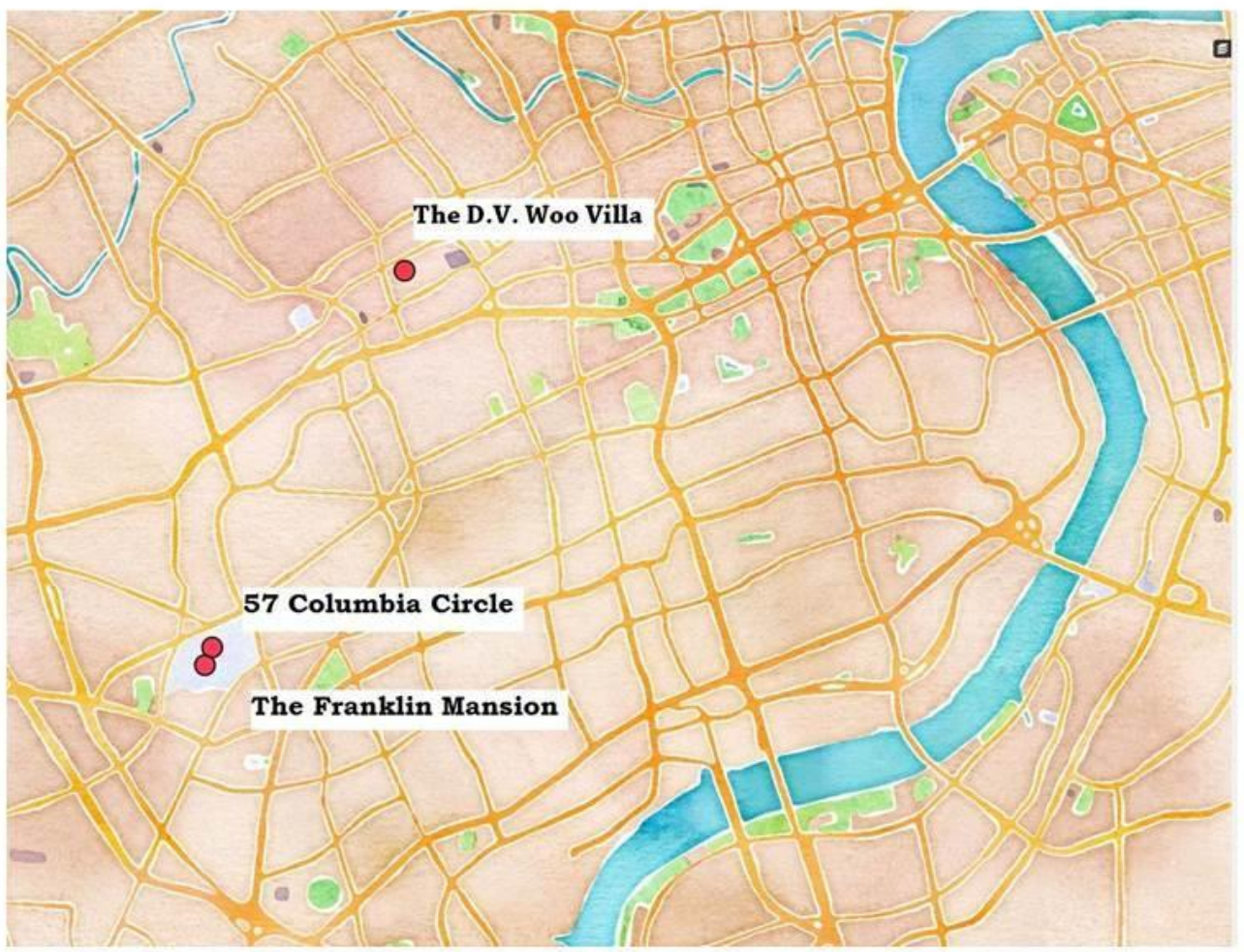

Fig. 1.7 Map showing location of case studies 


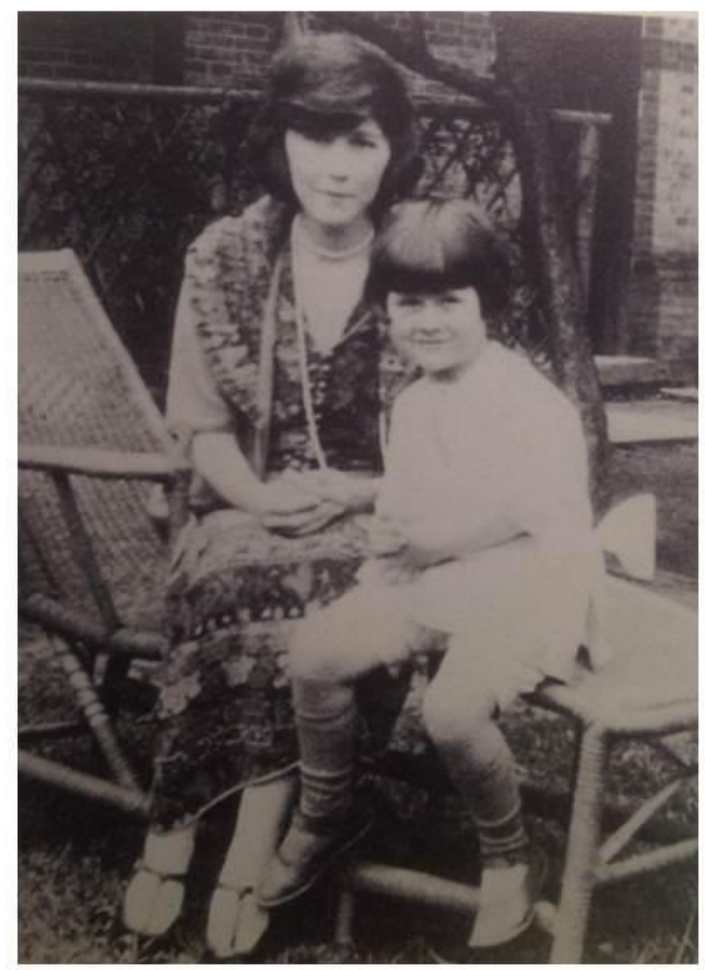

Fig. 3.1 Estelle Oldham in Shanghai

From: Joseph Blotner, Faulkner: A Biography. New York: Random House, (1984). 


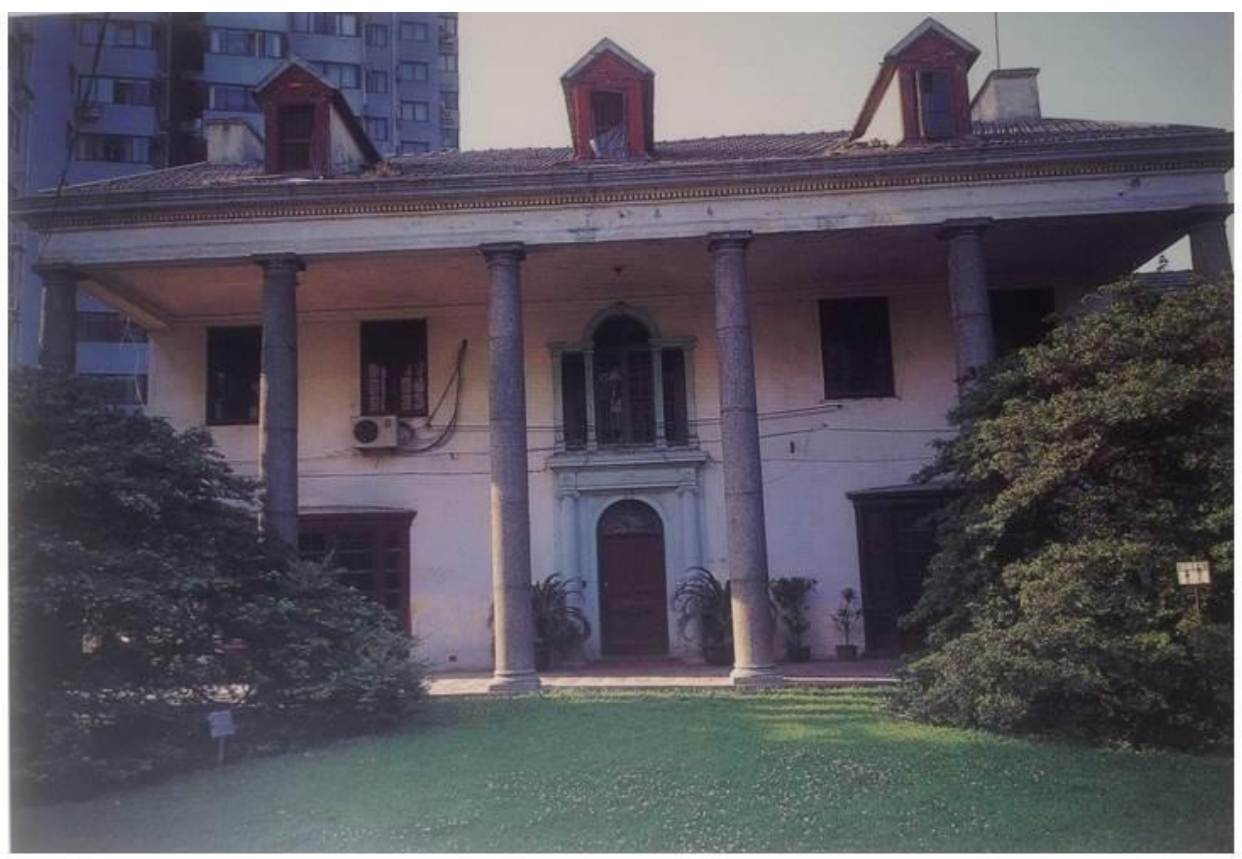

Fig. 3.2 The Franklin House, exterior.

From: Tess Johnston and Dongqiang Erh, Frenchtown Shanghai: Western Architecture in Shanghai's Old French Concession. 1st ed. Hong Kong: Old China Hand Press, 2000. 


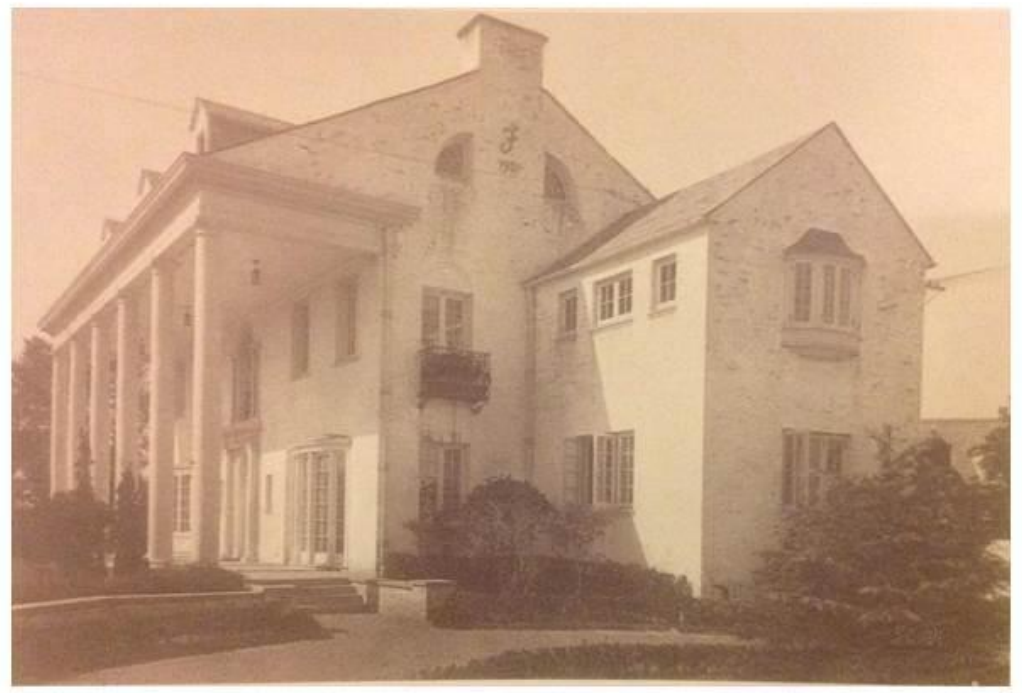

Fig. 3.3 The Franklin House, exterior, archival photograph.

From: Tess Johnston and Dongqiang Erh, Frenchtown Shanghai: Western Architecture in Shanghai's Old French Concession. 1st ed. Hong Kong: Old China Hand Press, 2000. 


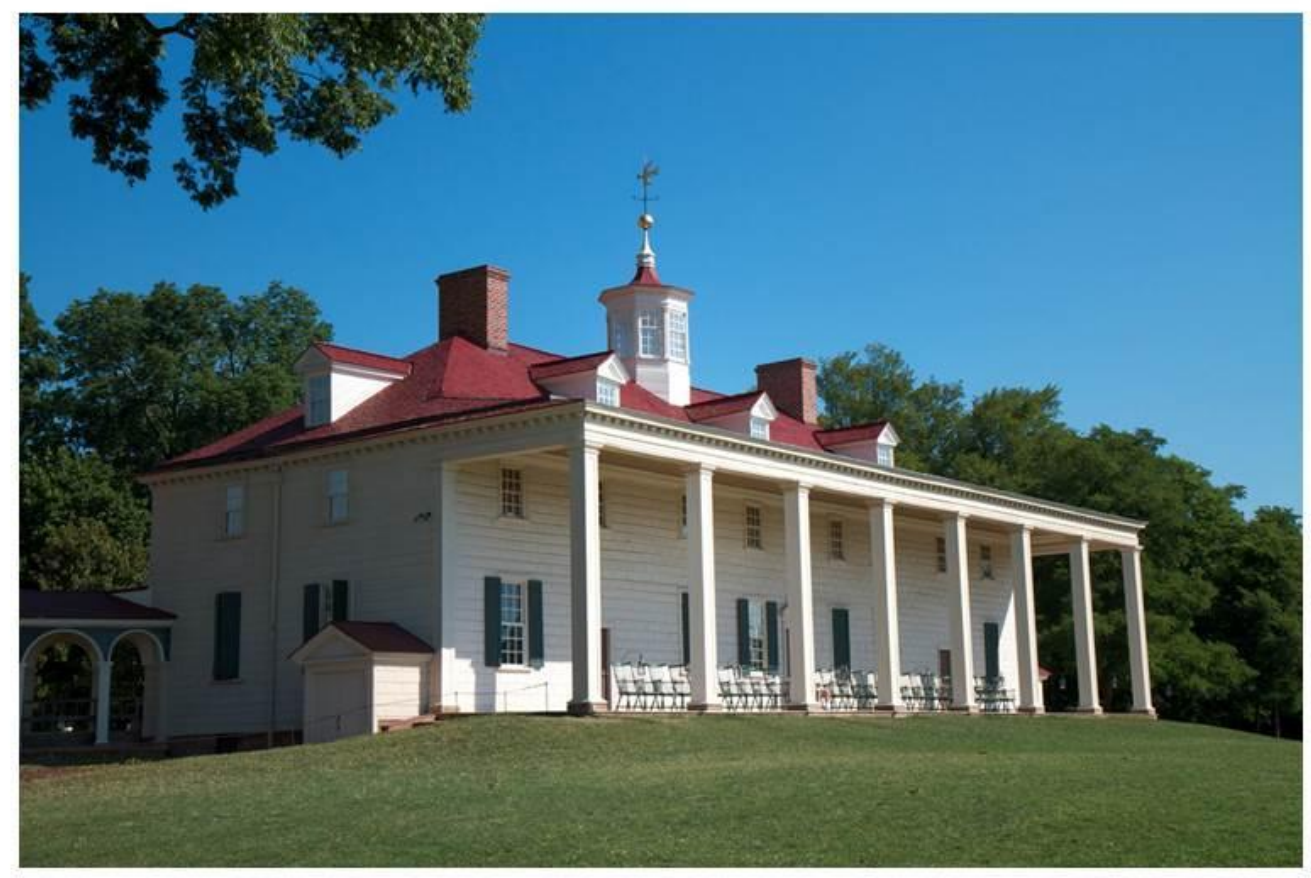

Fig. 3.4 Mount Vernon

From: Rob Shenk, Mount Vernon. Flickr, http://www.flickr.com/photos/rcsj/7428328252/sizes/l/ (accessed June 23, 2012). 


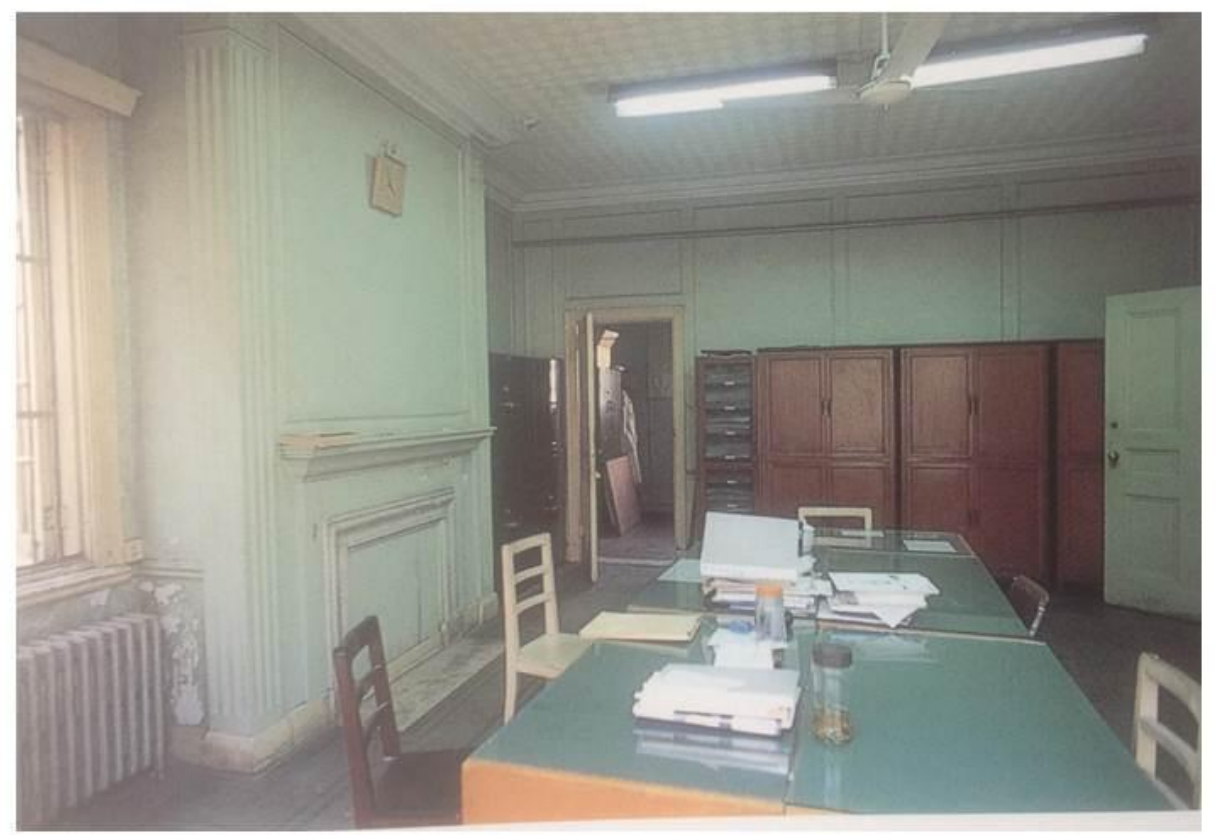

Fig. 3.5 The Franklin House, interior.

From: Tess Johnston and Dongqiang Erh, Frenchtown Shanghai: Western Architecture in Shanghai's Old French Concession. 1sted. Hong Kong: Old China Hand Press, 2000. 


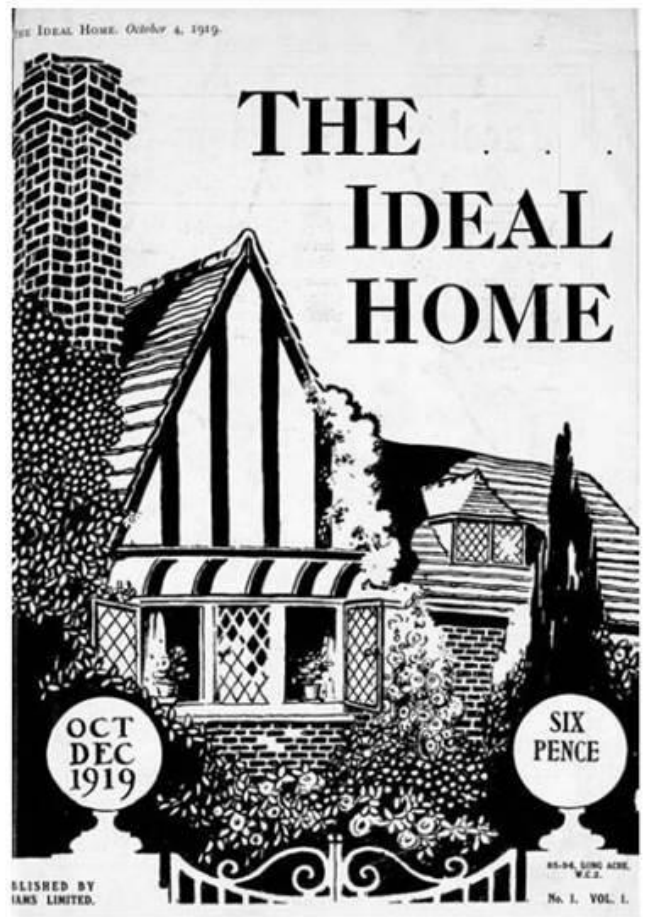

Fig. 4.1 The Ideal Home, Cover.

From: The Ideal Home, Volume 1 No. 1, October to December, 1919. 


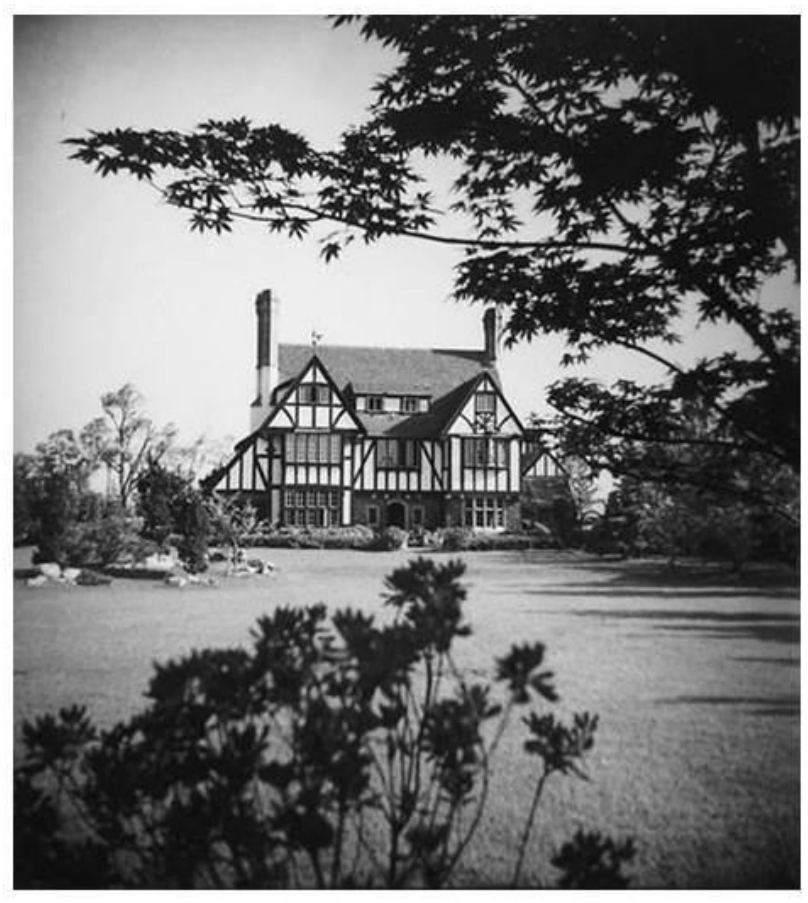

Fig. 4.2 57 Columbia Road, exterior and garden From: Lenore Hietkamp, "Understanding Laszlo Hudec, Shanghai Architect." Diamond River Books, accessed 02/01, 2014, http://www.heatherfieldediting.com/Hudec/index.html. 


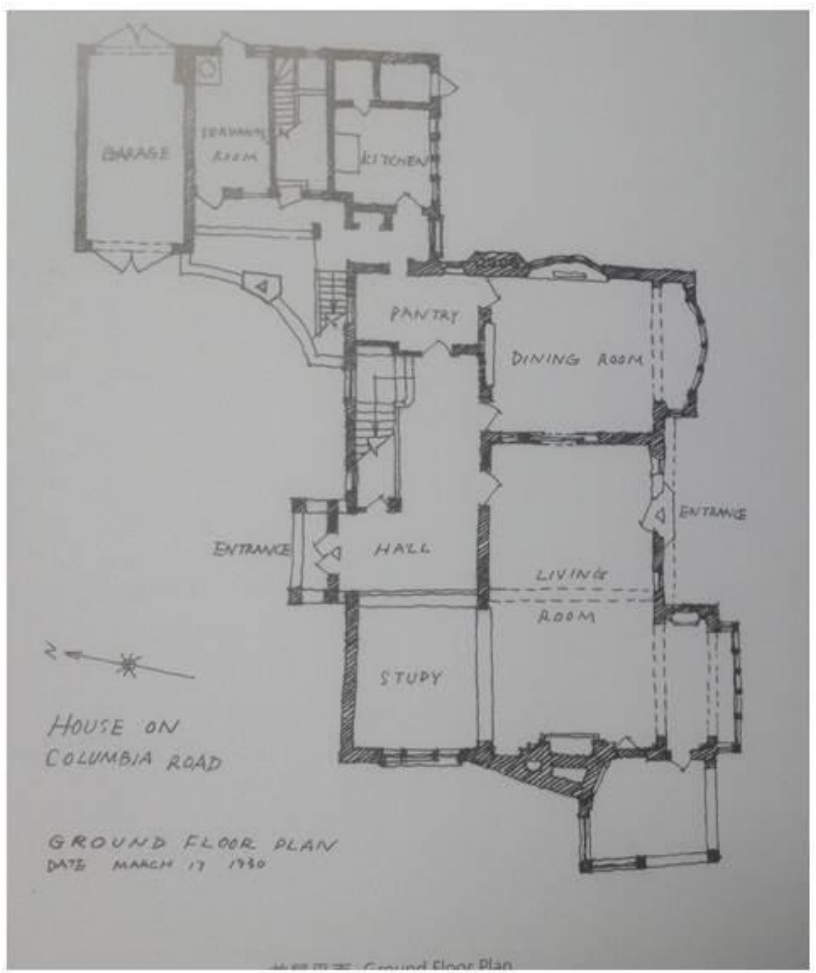

Fig 4.3 57 Columbia Circle, plan

Xiahong, Hua and Michelle Qiao. Shanghai Hudec Architecture. Shanghai: Tongji University Press, 2012. 


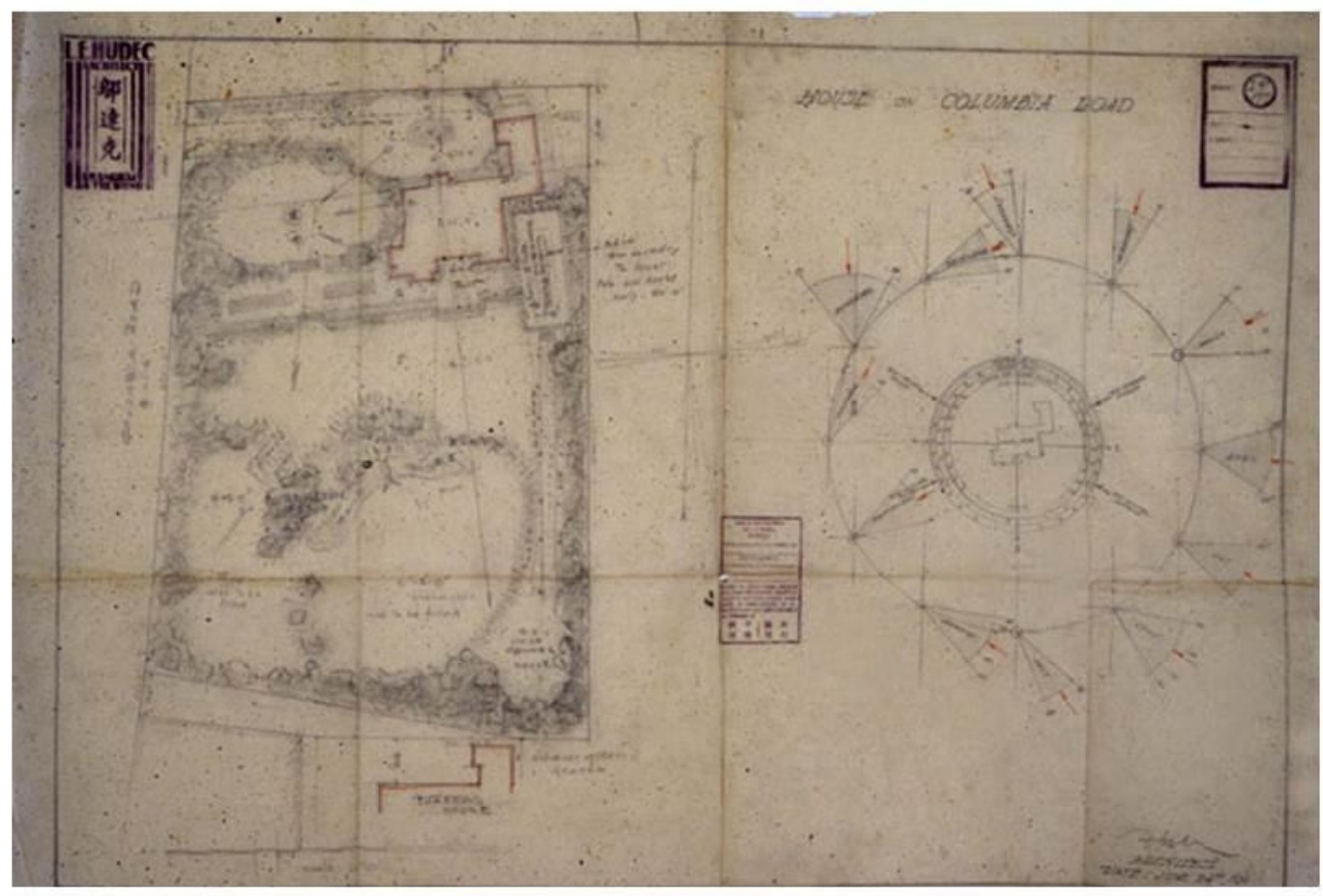

Fig. 4.4 57 Columbia Road, plan showing landscaping From: Lenore Hietkamp, "Understanding Laszlo Hudec, Shanghai Architect." Diamond River Books, accessed 02/01, 2014, http://www.heatherfieldediting.com/Hudec/index.html. 


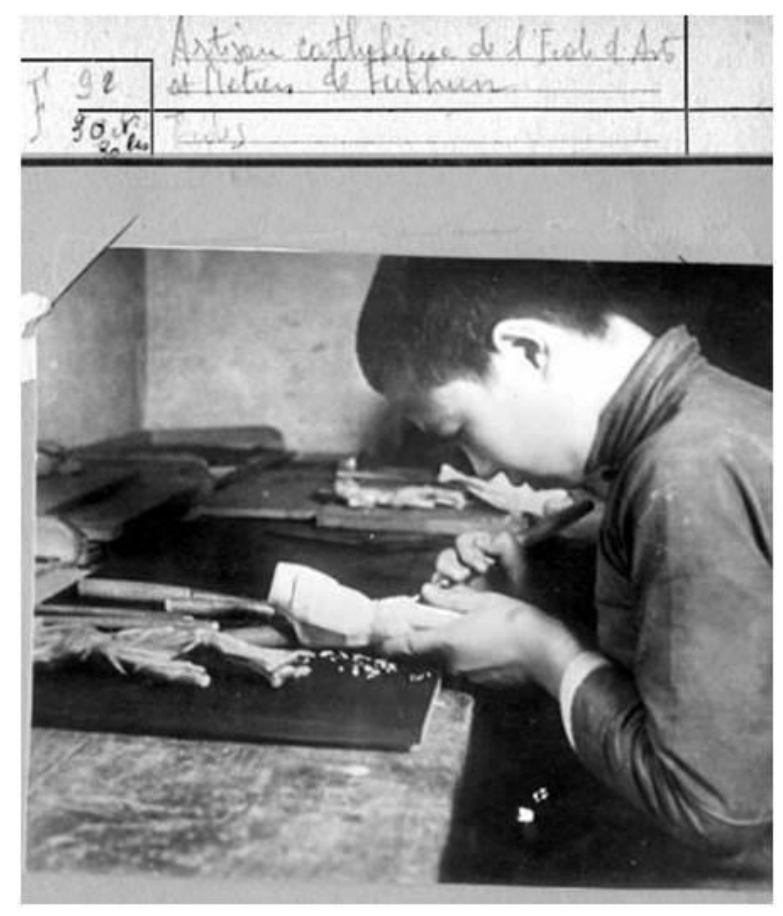

Fig. 4.5 Student in woodcarving workshop in Jesuit orphanage Lenore Hietkamp, "Understanding Laszlo Hudec, Shanghai Architect." Diamond River Books, accessed 02/01, 2014, http://www.heatherfieldediting.com/Hudec/index.html. 


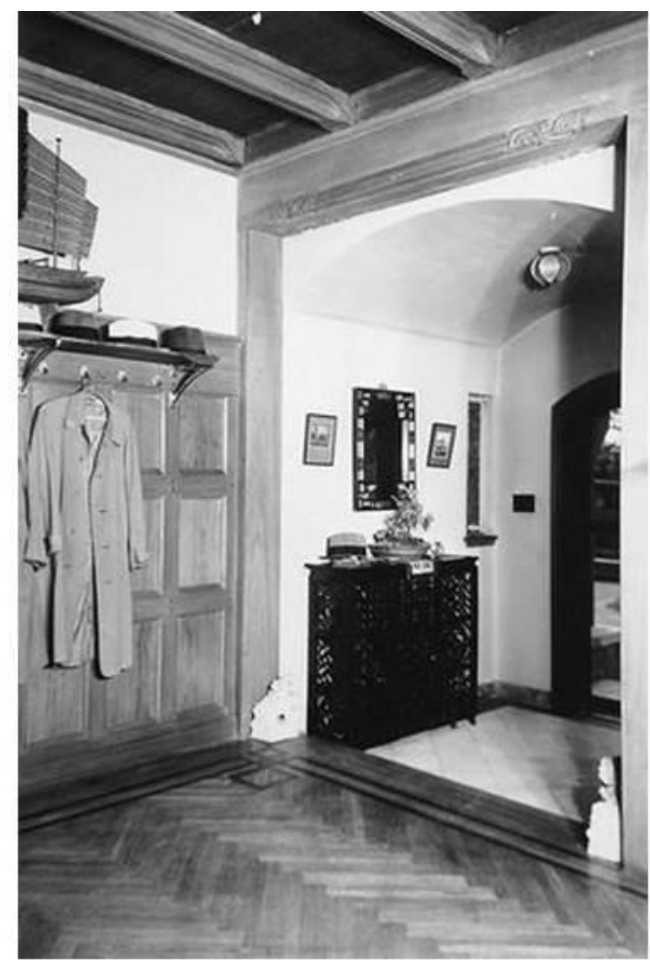

Fig. 4.657 Columbia Road, foyer

From: Lenore Hietkamp, "Understanding Laszlo Hudec, Shanghai Architect." Diamond River Books, accessed 02/01, 2014, http://www.heatherfieldediting.com/Hudec/index.html. 


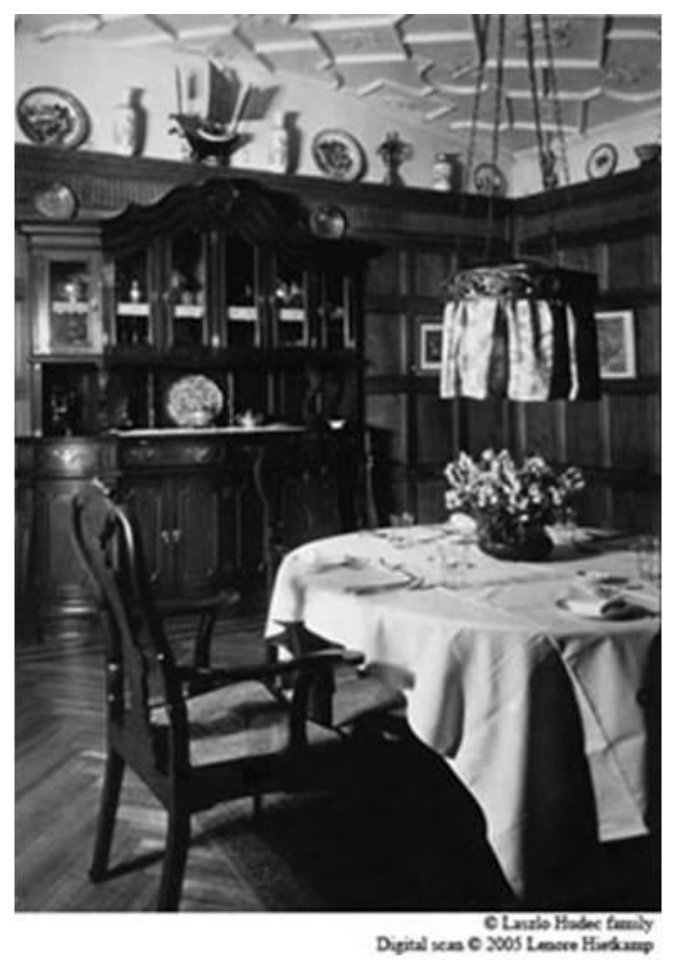

Fig. 4.757 Columbia Road, dining room

From: Lenore Hietkamp, "Understanding Laszlo Hudec, Shanghai Architect." Diamond River Books, accessed 02/01, 2014, http://www.heatherfieldediting.com/Hudec/index.html. 


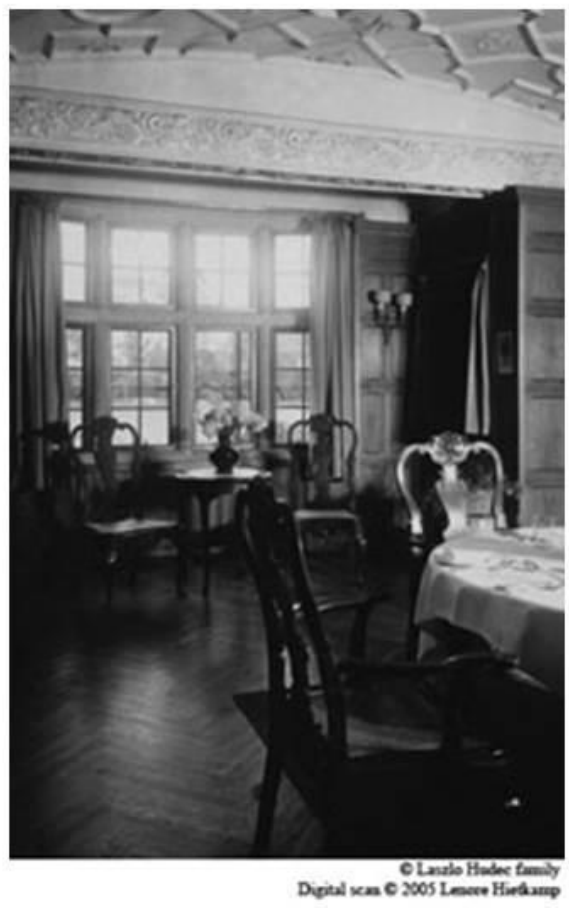

Fig. 4.757 Columbia Road, dining room

From: Lenore Hietkamp, "Understanding Laszlo Hudec, Shanghai Architect." Diamond River Books, accessed 02/01, 2014, http://www.heatherfieldediting.com/Hudec/index.html. 


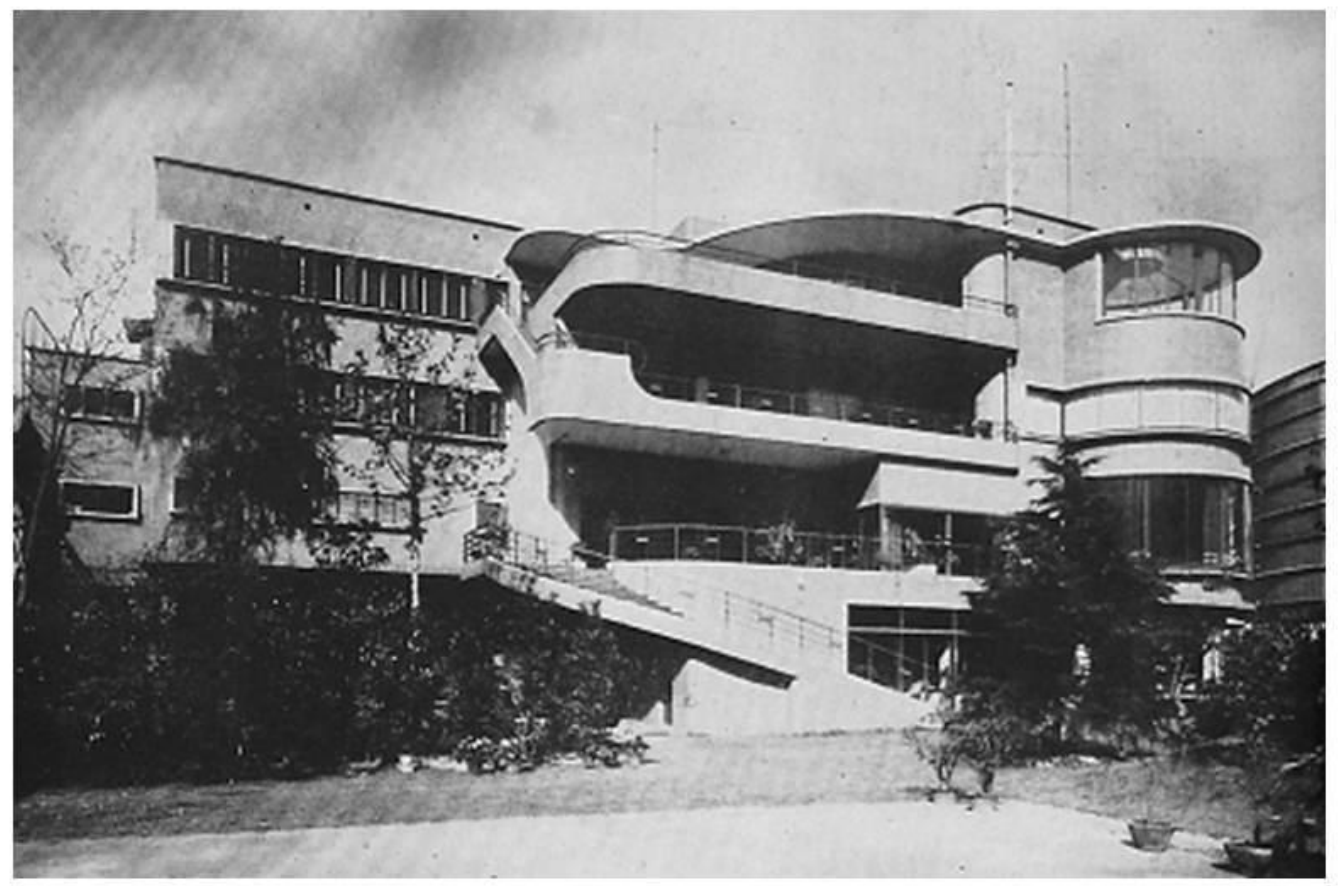

Fig 5.1 D.V. Woo House, view from the garden

From: "Fragments of Shanghai; Old Shanghai Architecture." The Flying Room, accessed 11/2, 2013,

http://www.theflyingroom.com/blogs/news/7515666-fragments-of-shanghaiold-shanghai-architecture. 


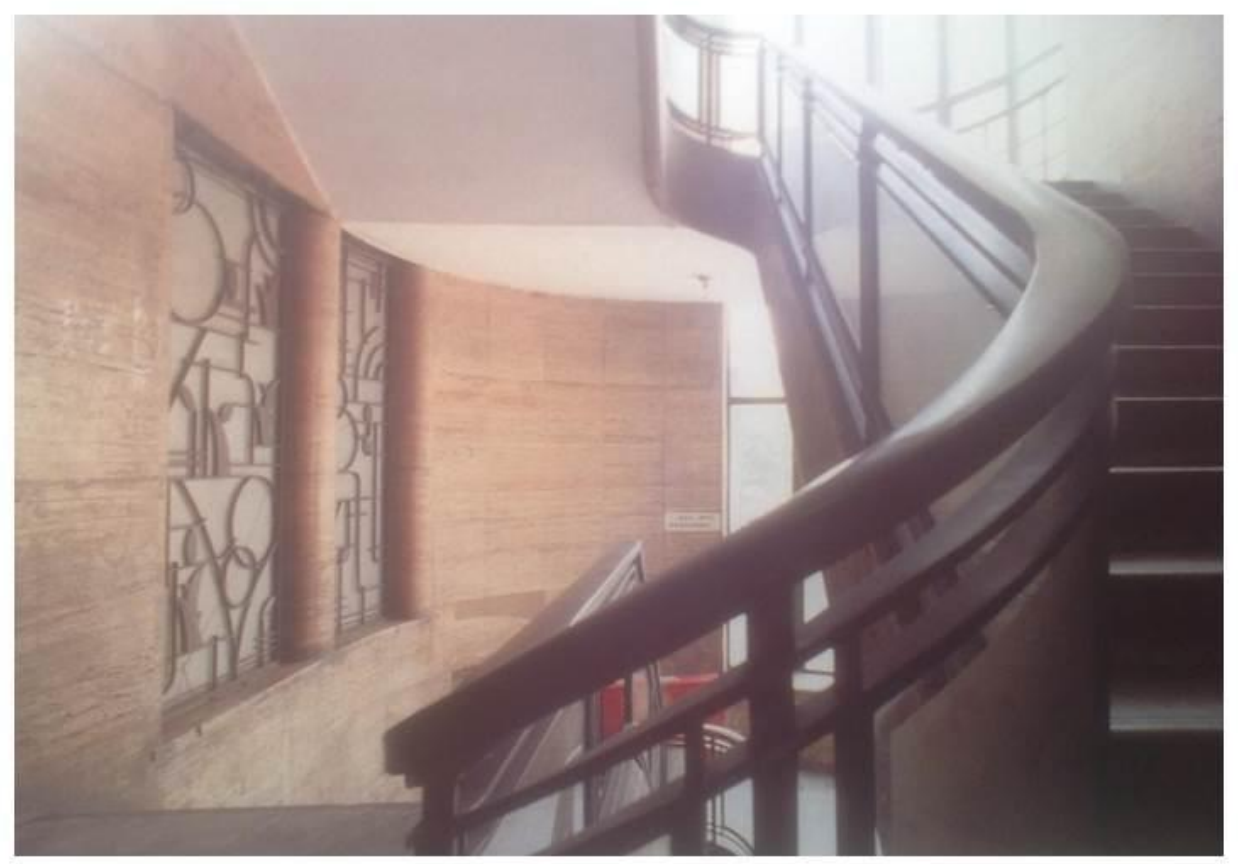

Fig 5.2 D.V. Woo House, interior stairwell featuring metal details Tess Johnston and Deke Erh. Art Deco Shanghai. Hong Kong: Old China Hand Press, 2006. 


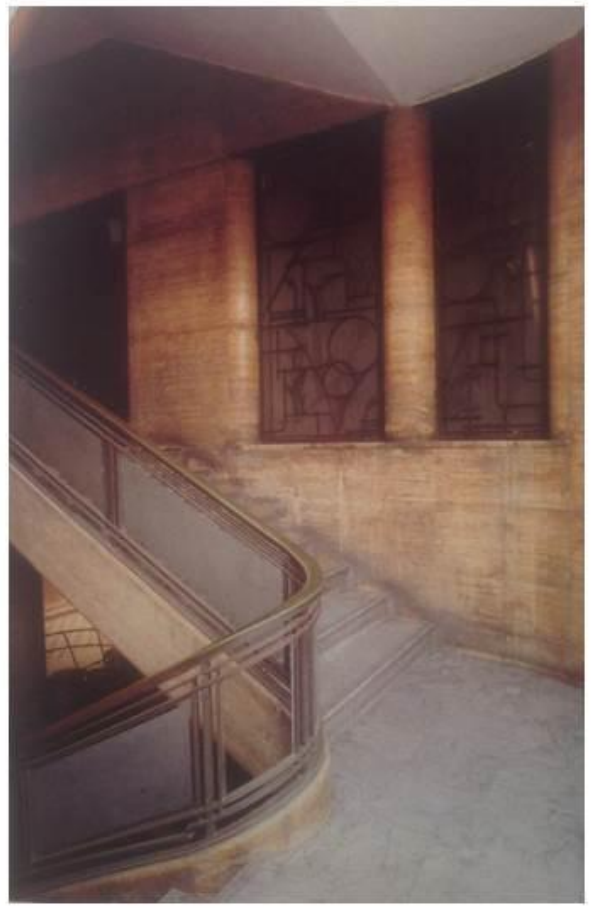

Fig 5.3 D.V. Woo House, interior stairwell featuring metal details Tess Johnston and Deke Erh. Art Deco Shanghai. Hong Kong: Old China Hand Press, 2006. 


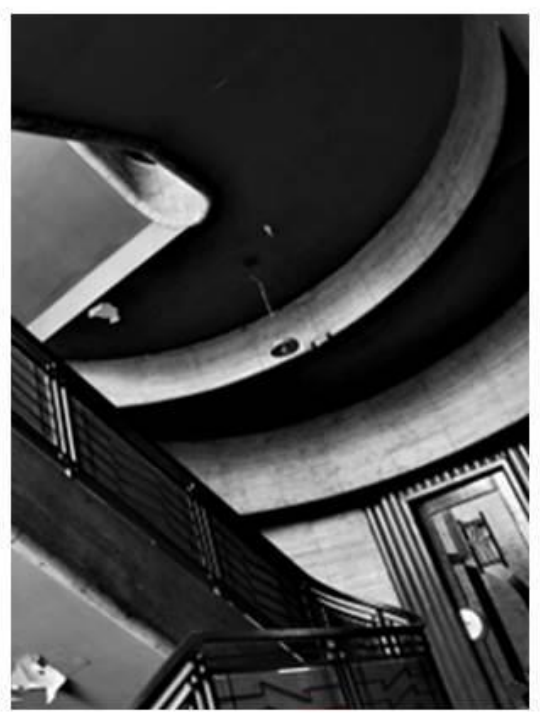

Fig 5.4 D.V. Woo House, interior stairwell

From: "Fragments of Shanghai; Old Shanghai Architecture." The Flying Room, accessed 11/2, 2013,

http://www.theflyingroom.com/blogs/news/7515666-fragments-of-shanghaiold-shanghai-architecture. 


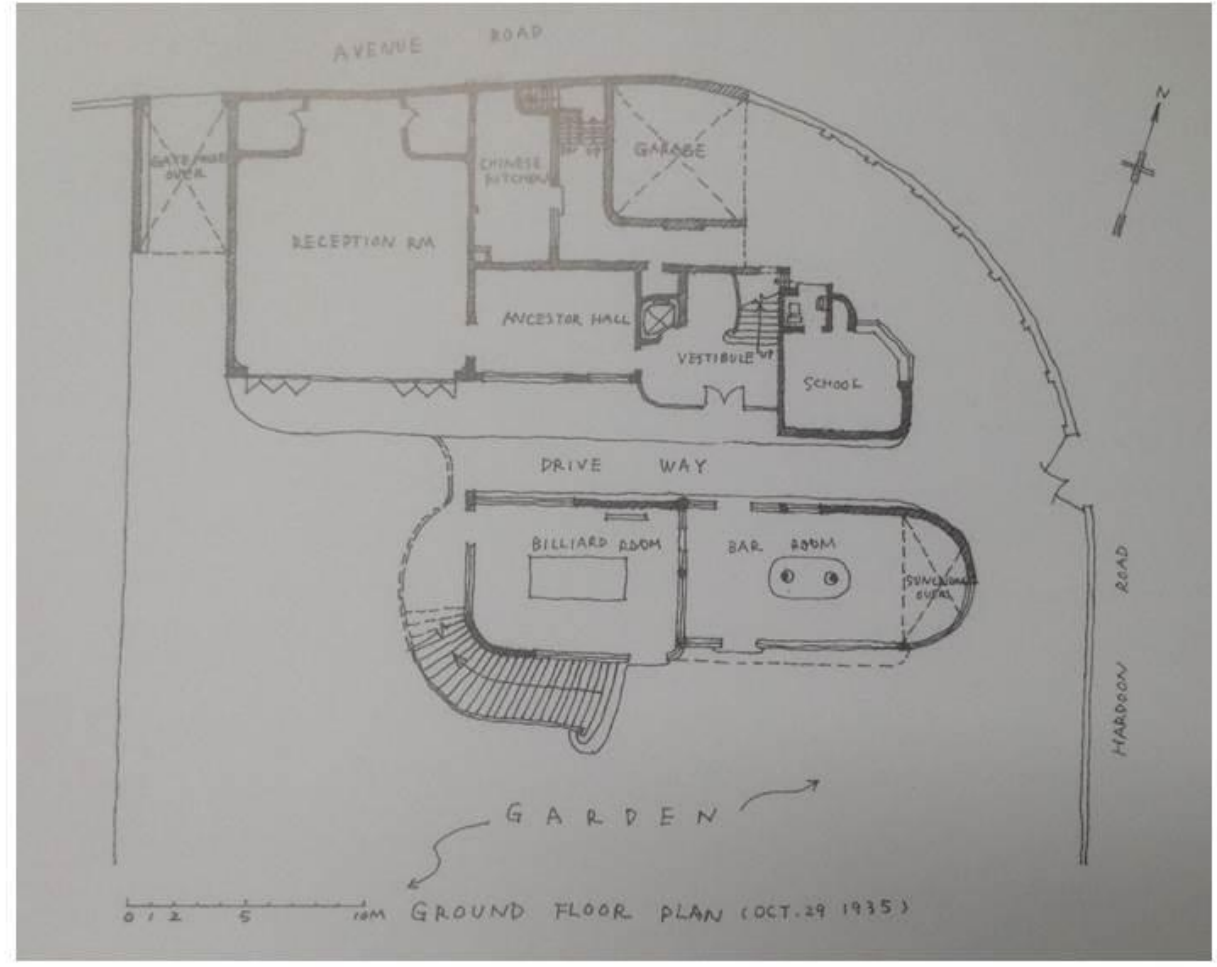

Fig 5.5 D.V. Woo House, ground floor plan

Xiahong, Hua and Michelle Qiao. Shanghai Hudec Architecture. Shanghai: Tongji University Press, 2012. 


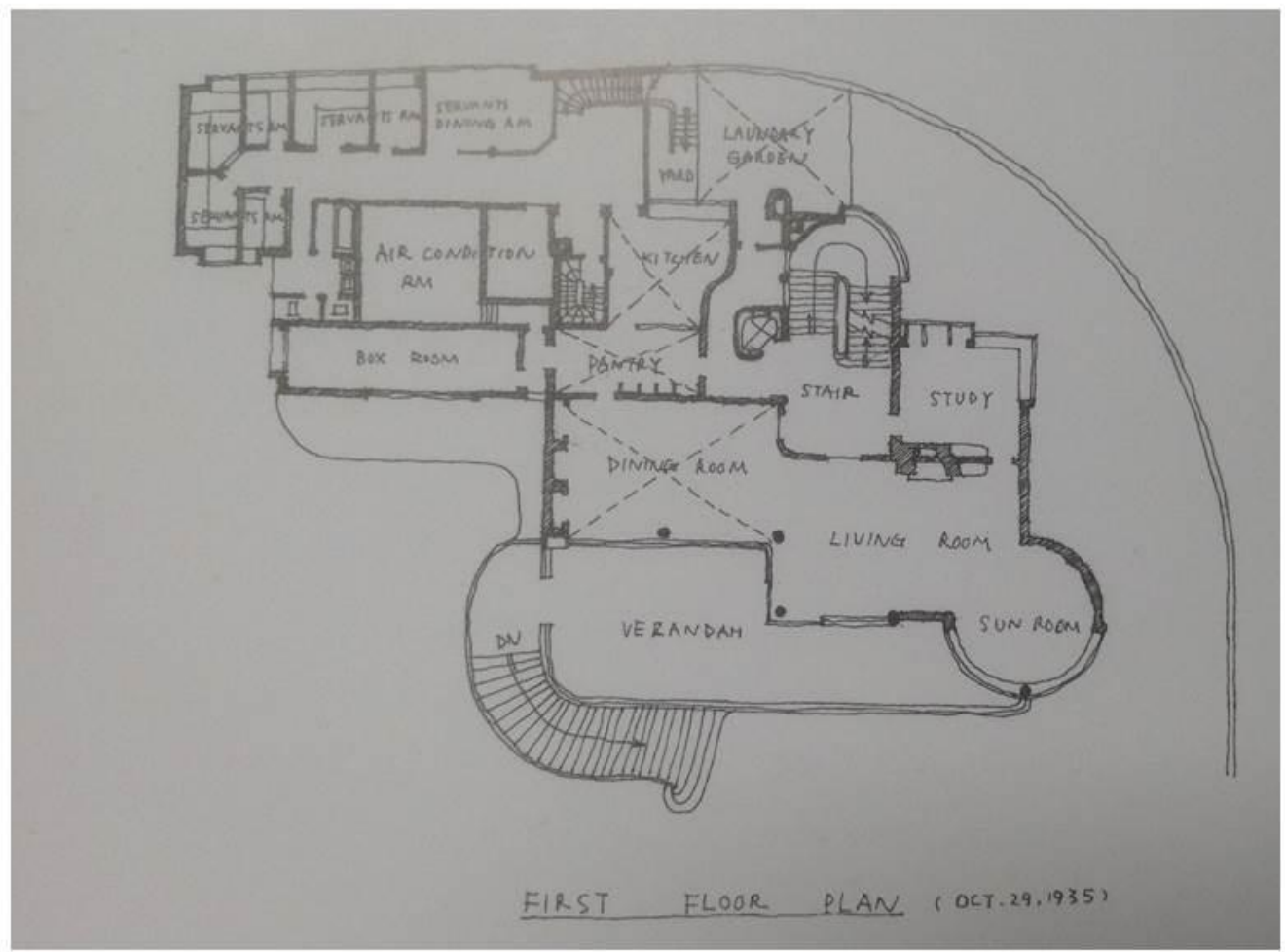

Fig 5.6 D. V. Woo House, first floor plan

Xiahong, Hua and Michelle Qiao. Shanghai Hudec Architecture. Shanghai: Tongji University Press, 2012. 


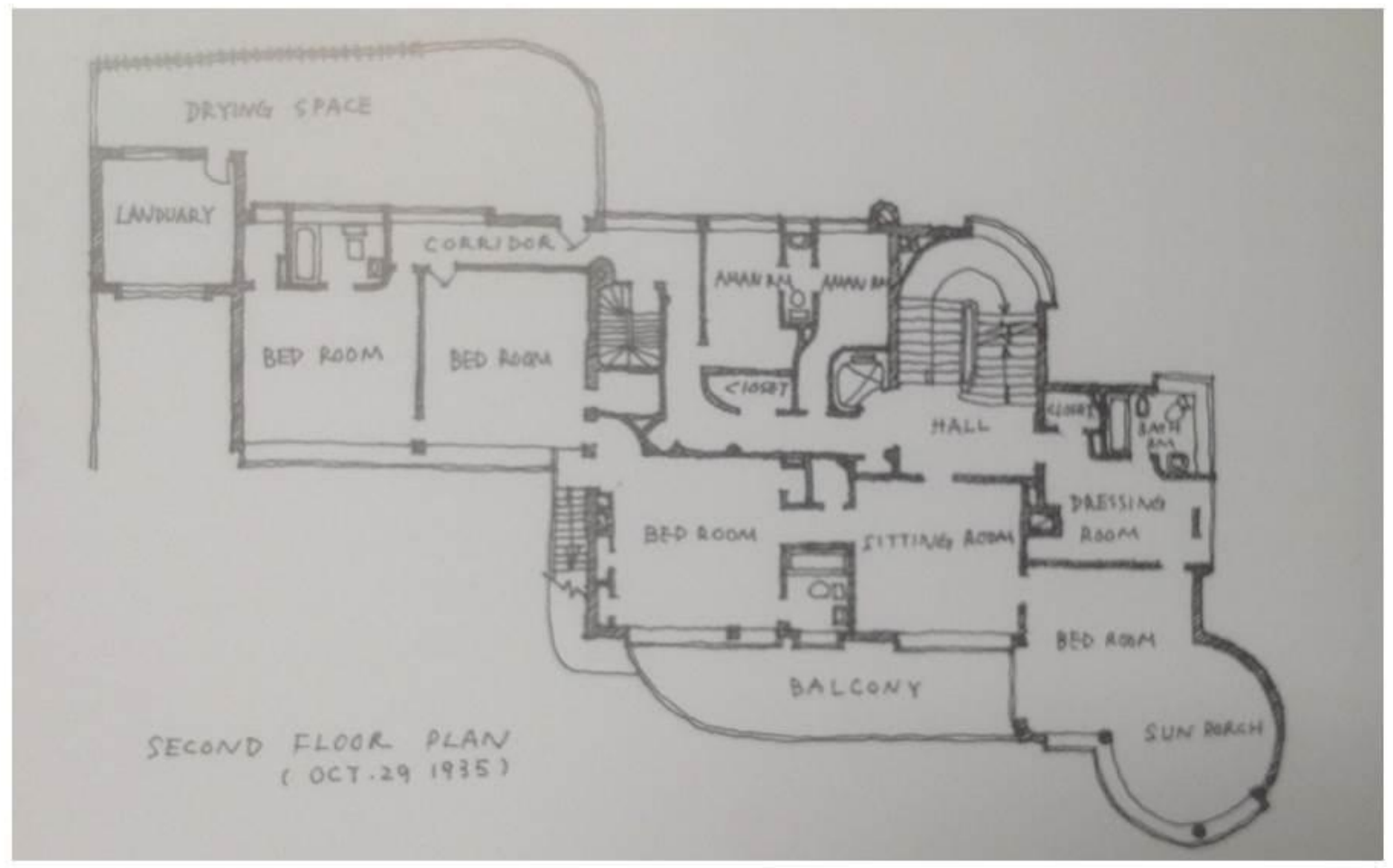

Fig 5.7 D.V. Woo House, second floor plan

Xiahong, Hua and Michelle Qiao. Shanghai Hudec Architecture. Shanghai: Tongji University Press, 2012. 


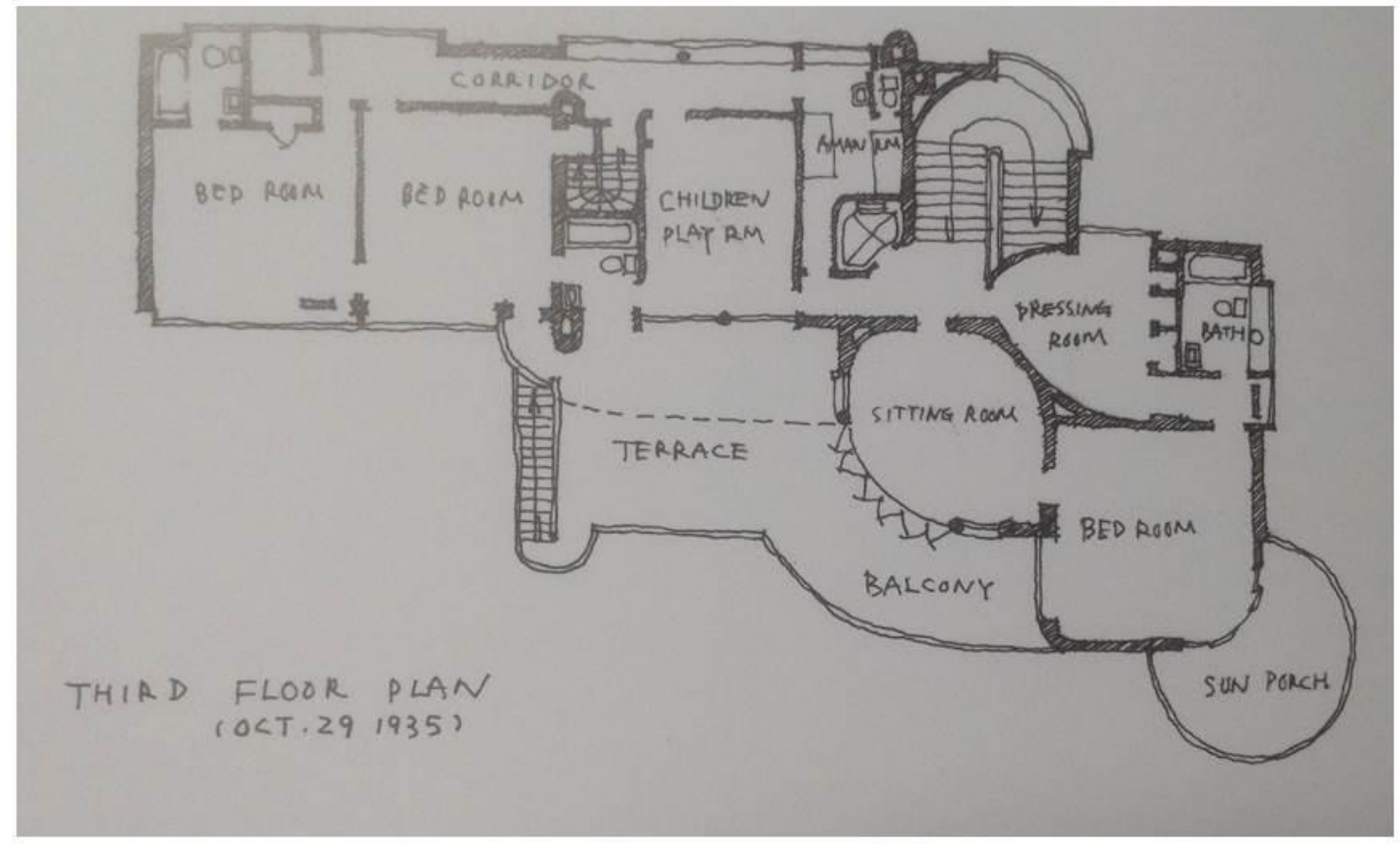

Fig 5.8 D.V. Woo House, third floor plan

Xiahong, Hua and Michelle Qiao. Shanghai Hudec Architecture. Shanghai: Tongji University Press, 2012. 


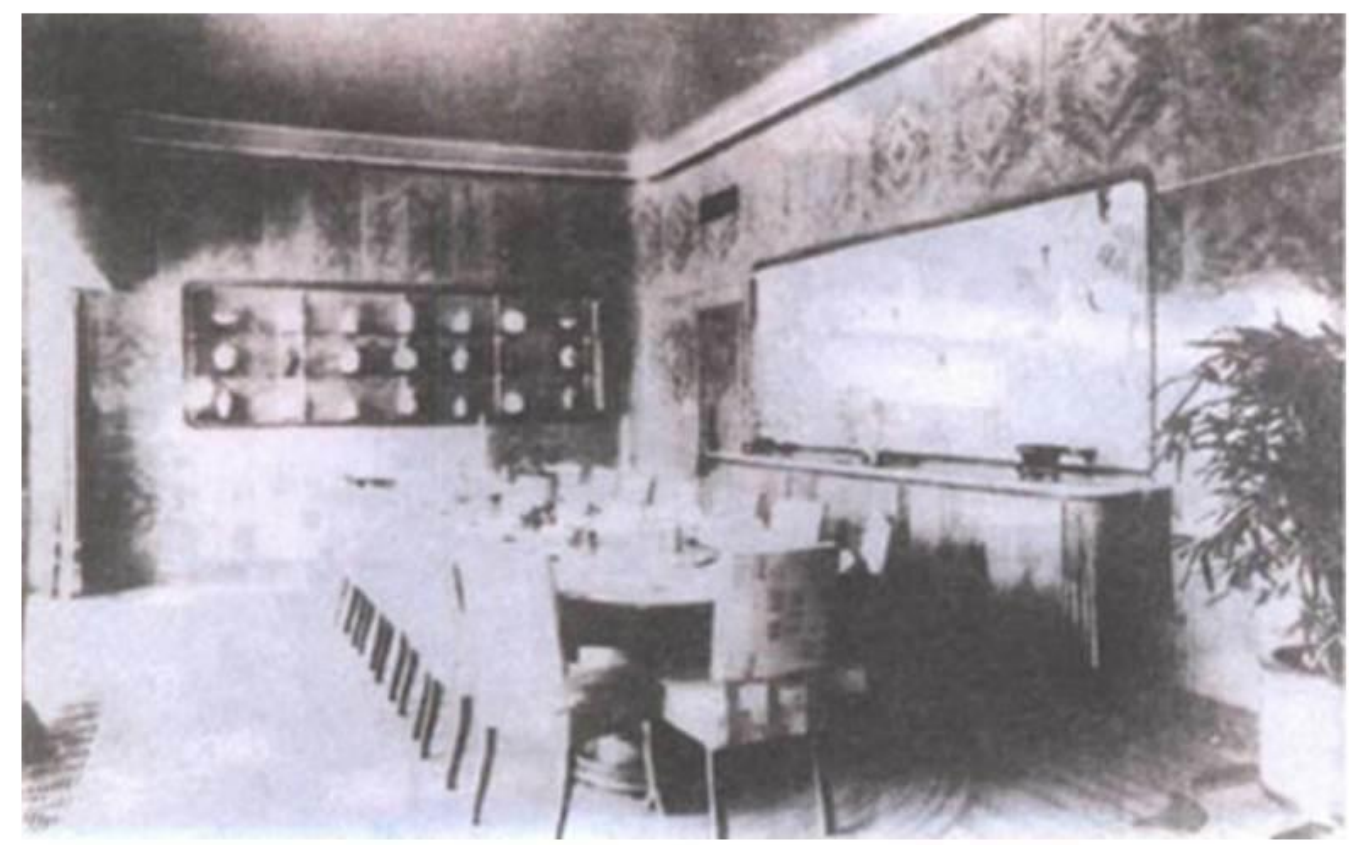

Fig 5.9 D.V. Woo House, dining room 吴同文住宅，上海市杨浦区图书馆，accessed 2/12, 2014. http://www.yplib.org.cn/upload/htmleditor/image/090330100544.jpg 